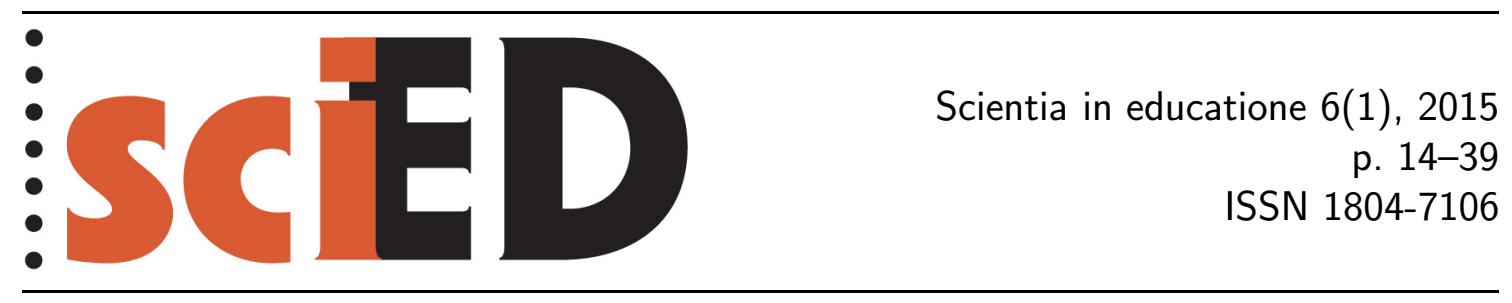

\title{
Výuka molekulární biologie na gymnáziích: analýza současného stavu a možnosti její podpory
}

\author{
Vanda Janštová, Martin Jáč
}

\begin{abstract}
Abstrakt
Molekulární biologie je rychle se rozvíjející vědní obor a s jejími metodami se setkáváme i v každodenním životě. Proto je důležité, aby byla zastoupena ve výuce biologie na gymnáziích. Jedním z cílů studie bylo analyzovat rozložení vzdělávacího obsahu molekulární biologie na úrovni gymnaziálních školních vzdělávacích programů (ŠVP) do jednotlivých ročníků a zjistit, která molekulárně biologická témata jsou v ŠVP zastoupena a jak často. Dalším cílem bylo otestovat srozumitelnost a atraktivitu pokročilých molekulárně biologických laboratorních cvičení určených pro žáky střední školy. ŠVP celkem 160 gymnázií ze všech krajů ČR byly hodnoceny z hlediska zařazení deseti tematických kategorií výukového obsahu molekulární biologie ve vyučovacích předmětech biologie, chemie a volitelných biologických a chemických seminářích. Data byla analyzována shlukovou analýzou a následným $\chi^{2}$ testem nezávislosti. V letech 2011-2013 byly realizovány čtyři různé typy praktických cvičení z molekulární biologie, kterých se zúčastnilo 466 žáků středních škol. Cvičení probíhala bud' na Př́rodovědecké fakultě Univerzity Karlovy v Praze, nebo na středních školách, vedl je vysokoškolský lektor nebo středoškolský učitel. Po ukončení cvičení žáci vyplnili reflektivní dotazník, ve kterém laboratorní cvičení zhodnotili. Získaná data byla zpracována pomocí analýzy rozptylu. Výsledky ukazují, že molekulárně biologická témata jsou do výuky na gymnáziích zařazena převážně izolovaně v posledním ročníku povinné výuky biologie či chemie. Řada témat je v rámci povinné výuky opomíjena, prŕpadně je zařazena pouze $\mathrm{v}$ povinně volitelných seminářích. Realizovaná molekulárně biologická cvičení byla žáky celkově hodnocena velmi kladně. Byly zjištěny rozdíly hodnocení cvičení v závislosti na typu cvičení, na vyučujícím a místě průběhu laboratorního cvičení. Na základě výsledků je možné doporučit více provázat učivo molekulární biologie a ostatních biologických oborů a zařazovat pokročilá laboratorní cvičení do výuky.
\end{abstract}

Klíčová slova: molekulární biologie, výuka, gymnázium, školní vzdělávací program, laboratorní cvičení. 


\title{
Teaching Molecular Biology at Grammar Schools: Analysis of the Current State and Potential of its Support
}

\begin{abstract}
Molecular biology is a very progressive field of science. Moreover, its methods and results are closely connected with our everyday lives. It is therefore crucial to implement this field into grammar school biology curriculum. The first aim of this study was to analyse how the molecular biology content is distributed into different years in School Education Programmes (SEPs) of Czech grammar schools and which molecular biology topics are included and how often. Another aim of the study was to test the comprehensibility and attractiveness of advanced molecular biology laboratory courses for grammar school students. The implementation of molecular biology topics into compulsory and optional biology and chemistry classes in the SEPs of 160 grammar schools was evaluated together with their distribution into different years. The data was analysed by a cluster analysis and subsequent $c h i$-square test for independence. During years 2011-2013, we organized four different types of laboratory courses focused on molecular biology topics. The laboratory courses took place at the Faculty of Science, Charles University in Prague or at participating grammar schools and were taught by a university lecturer or a grammar school biology teacher. Students who participated in the courses $(n=466)$ filled in an evaluation questionnaire at the end of the laboratory exercise. The data was analysed by the analysis of variance. The results indicate that molecular biology topics in the SEPs are mostly included in a single year (usually the last year of compulsory biology and chemistry education). Some of the topics were not included in the majority of compulsory classes and were found mainly in optional classes. The practical laboratory courses were rated very positively by students. Significant differences were found in ratings of different types of courses. Student ratings were also dependent on other variables (lecturer, site of the course). Based on the results, our conclusion is that molecular biology should be implemented in the grammar school curriculum much more with the support of advanced laboratory courses.
\end{abstract}

Key words: molecular biology, instruction, grammar school, school education programme, laboratory exercise. 


\section{1 ÚVOD}

Molekulární biologie je jednou z biologických disciplín, která v posledních dekádách prodělala rychlý rozvoj, a dnes jsou její metody rutinně využíány v celé řadě biologických i medicínských odvětví. Díky molekulárně biologickým metodám jsou dnes upřesňovány vztahy mezi organismy, konstruovány geneticky modifikované organismy (GMO), s nimiž se pojí velká očekávání i emoce, aktuální se stává také diagnostika na základě analýzy sekvencí DNA jednotlivých pacientů i genová terapie. Je to tedy obor biologie, se kterým se čím dál tím častěji budeme setkávat v našem každodenním životě. Jako občané se navíc musíme rozhodovat, jaký postoj zaujmeme např́klad ke GMO nebo genové terapii. Z těchto důvodů je více než žádoucí, aby výuka molekulární biologie včetně jejích metod byla součástí biologického kurikula na středních školách.

\section{TEORETICKÁ VÝCHODISKA}

Molekulární biologie patří mezi abstraktní obory a pro žáky je často obtížné porozumět jejím konceptům a reálně si je představit (Lewis \& Wood-Robinson, 2000). Z tohoto důvodu je, převážně v zahraničí, rozpracováno několik didaktických přístupů, pomocí kterých lze molekulárně biologické poznatky žákům zprostředkovat. Vědci běžně používají bioinformatické přístupy při práci s genovými databázemi, např. při zpracovávání sekvencí DNA. Jednou z možností, jak přiblížit výuku molekulární biologie skutečné práci profesionálních biologů, je právě výuka bioinformatiky. K dispozici je řada metodických návodů a námětů pro konkrétní využití ve výuce na středních školách (Wefer \& Anderson, 2008; Offner \& Pohlman, 2010; Gallagher et al., 2011; Ondřej \& Dvořák, 2012; Wood \& Gebhardt, 2013). V USA není bioinformatika součástí středoškolských standardů žádného z federálních států a také na úrovni kurikula je zastoupena relativně málo, nejvíce v kontextu evoluce, mutací a klasifikace organizmů (Wefer \& Sheppard, 2008). Využití bioinformatiky ve výuce vedlo ke zlepšení schopnosti žáků vysvětlit souvislosti, zdůvodňovat fakta a využívat v diskuzi o genetických tématech relevantní argumenty. Kromě toho žáci lépe chápali principy vědecké práce (Gelbart \& Yarden, 2006; Tsui \& Treagust, 2003, 2007), i když míra nově nabytých znalostí byla různá podle typologie žáků - autoři rozlišují žáky zaměřené na výzkumné postupy a žáky zaměřené na plnění úkolu (viz Gelbart, Brill \& Yarden, 2009). Je zřejmé, že pro zabezpečení kvalitní výuky bioinformatiky na středních školách je nutné zajistit další vzdělávání učitelů biologie a zařadit bioinformatiku do př́pravy budoucích učitelů biologie. Evropská organizace pro molekulární biologii (European Molecular Biology Organization; EMBO), proto pořádá kurzy bioinformatiky pro středoškolské učitele (Wood \& Gebhardt, 2013). V květnu 2014 tento kurz poprvé proběhl i v České republice.

Další možností při výuce molekulárně biologických témat je využití modelů, které si žáci sami vyrobí. Názornost modelu tak může zlepšit představy žáků o strukturách a procesech, které ve středoškolské výuce nelze běžně pozorovat (Malacinski \& Zell, 1996; Srinivasan, 1998; Byrd, 2000; Donovan \& Venville, 2005; Balgopal \& Bondy, 2011). Podobný význam pro zvýšení srozumitelnosti výkladu molekulárně biologických témat má využívání analogií (Venville \& Donovan, 2006; Woody \& Himelblau, 2013). Jako možné a vhodné se ukazuje i využití odborných a populárně naučných výukových textů či animací (Bowling, Zimmer \& Pyatt, 2014; Drits-Esser et al., 2014). 
Řada autorů prokázala, že je možné efektivně odbourat miskoncepty žáků během výuky molekulárně biologických praktických cvičení (Franke \& Bogner, 2011). Tato praktická cvičení nejčastěji probíhají na specializovaných pracovištích (Ben-Nun, Stolarsky \& Yarden, 2009; Scharfenberg \& Bogner, 2013a, b). Obdobně je v České republice možné provést praktická cvičení ve spolupráci s univerzitami nebo pracovišti Akademie věd ČR. Na Př́rodovědecké fakultě Univerzity Karlovy v Praze probíhají molekulárně biologická praktická cvičení již pátým rokem (Falteisek, Černý \& Janštová, 2013; Janštová, Pavlasová \& Černý, 2014).

V České republice je na úrovni kurikulárních dokumentů stanoven vzdělávací obsah jednotlivých vzdělávacích oborů na gymnáziu (včetně biologie) Rámcovým vzdělávacím programem pro gymnázia (RVP G, 2007). Vzdělávací obsah je tvořen učivem a očekávanými výstupy, které tvoří vzájemně velmi úzce provázaný celek, přičemž je učivo v RVP G „chápáno jako prostředek k dosažení stanovených očekávaných výstupư (RVP G, 2007: s. 12). Vzdělávací obsah oboru biologie je v RVP G rozčleněn celkem do deseti tematických okruhů, které zahrnují základní dílčí disciplíny oboru. Molekulární biologie je v kontextu vzdělávacího obsahu oboru biologie v RVP G explicitně zmíněna pouze v tematickém okruhu genetika na úrovni učiva „molekulární a buněčné základy dědičnosti“ (RVP G, 2007: s. 34). V tematickém okruhu obecná biologie je možné dovodit, že znalosti z molekulární biologie bude žák potřebovat k dosažení očekávaného výstupu, kdy ,žák objasní stavbu a funkci strukturních složek a životní projevy prokaryotních a eukaryotních buněk“ v rámci učiva „buňka stavba a funkce" (RVP G, 2007: s. 31). Obdobně v tematickém okruhu biologie virů je zahrnuto učivo „stavba a funkce virů“, k jehož osvojení a dosažení očekávaného výstupu „žák charakterizuje viry jako nebuněčné soustavy“ (RVP G, 2007: s. 31) jsou potřeba alespoň základní znalosti z molekulární biologie. Molekulární biologie je tedy ve vzdělávacím obsahu oboru biologie v RVP G zařazena poměrně izolovaně, přičemž z formulací očekávaných výstupů a učiva převážné části tematických okruhů (viz např. biologie rostlin, biologie hub, biologie živočichů a biologie člověka; RVP G, 2007: s. 32-33) není zřejmé, zda je postačující osvojení učiva a dosažení očekávaných výstupů na úrovni orgánové, buněčné či molekulární. Kromě vzdělávacího oboru biologie je molekulárně biologická tematika v RVP G zařazena také ve vzdělávacím oboru chemie, konkrétně v tematickém okruhu biochemie. Součástí tohoto tematického okruhu je mimo jiné učivo „proteiny, nukleové kyseliny“, přičemž očekávané výstupy reflektují úlohu těchto biologických makromolekul v živých organismech (RVP G, 2007: s. 31). Molekulární biologie má kromě vzdělávacích oborů biologie a chemie také vztah ke vzdělávacímu oboru výchova ke zdraví. Vzdělávací obsah tohoto oboru zahrnuje např́klad témata péče o reprodukční zdraví, metody asistované reprodukce či rizika ohrožující zdraví a jejich prevence (RVP G, 2007: s. 58-60), přičemž tato témata souvisejí s problematikou cytogenetiky či mutací.

Vzhledem ke značnému významu molekulární biologie, která zasahuje do všech oblastí biologického výzkumu a tvoří jeden ze základních konceptů současné biologie (viz napřr. Nurse, 2003), považujeme za nutné, aby byla tato disciplína zastoupena ve výuce na gymnáziích a tedy na úrovni gymnaziálních školních vzdělávacích programů (ŠVP). Prvním z cílů této studie bylo analyzovat zastoupení molekulární biologie v ŠVP gymnázií v učebních osnovách vyučovacích předmětů biologie, chemie a volitelných seminářu z biologie a chemie. Proto jsme si položili dvě výzkumné otázky, na které jsme se snažili najít odpověd:

1. Která témata molekulární biologie jsou v učivu a očekávaných výstupech na úrovni ŠVP zastoupena a jaká je jejich četnost? 
2. Jaké je rozložení vzdělávacího obsahu molekulární biologie na úrovni ŠVP v jednotlivých ročnících gymnázia?

Očekáváme, že zastoupení konkrétních molekulárně biologických témat bude na úrovni ŠVP, vzhledem k decentralizovanému způsobu tvorby tohoto kurikulárního dokumentu, značně různorodé. Dále předpokládáme, že molekulární biologie bude do učebních osnov vyučovacích předmětů v ŠVP (biologie, chemie a volitelné semináře z biologie a chemie) zařazena spíše izolovaně (převážně v rámci jednoho ročníku).

Dalším z cílů naší studie bylo otestovat srozumitelnost a atraktivitu pokročilých laboratorních cvičení z molekulární biologie pro žáky středních škol. V tomto ohledu nás zajímalo, které faktory mohou mít vliv na hodnocení praktických cvičení z molekulární biologie žáky středních škol. V našem výzkumu jsme se zaměřili na 3 hlavní faktory: typ laboratorního cvičení, místo konání laboratorního cvičení a osobu lektora vedoucího daného cvičení, sledovali jsme ale také vliv pohlaví či ročníku střední školy. Předpokládali jsme, že prostředí vysoké školy a zkušenosti vysokoškolského lektora s realizací cvičení z molekulární biologie mohou mít pozitivní vliv na vnímání (hodnocení) praktických cvičení žáky.

\section{Metodika}

\subsection{KOMPARATIVNí ANALÝZA GYMNAZIÁLNÍCH ŠKOLNíCH VZDĚLÁVACÍCH PROGRAMŮ}

Při sestavení souboru gymnaziálních školních vzdělávacích programů jsme vycházeli ze seznamu gymnázií zapsaných v Rejstříku škol a školských zařízení Ministerstva školství, mládeže a tělovýchovy (Rejstřík škol a školských zařízení MŠMT, 2014, verze 2.39, stav k 26. září 2014) a z něj vycházejícího Adresáře škol a školských zařízení MŠMT a Ústavu pro informace ve vzdělávání (Adresář škol a školských zařízení MŠMT a UIV, 2014, revize 1212003, stav k 26. zář́i 2014). Podle seznamu a adresáře gymnázií zapsaných v Rejstř́ku škol a školských zařízení (celkem 381 gymnázií k 26. září 2014) jsme z webových stránek jednotlivých škol získávali jejich aktuální ŠVP. Celkem se nám podařilo shromáždit 160 ŠVP (42 \% gymnázií v České republice), přičemž u 106 škol (27,8 \% gymnázií v České republice) z tohoto souboru jsme měli $\mathrm{k}$ dispozici osnovy ŠVP pro volitelný předmět seminář z biologie a 108 ŠVP obsahovalo osnovy pro volitelný předmět seminář z chemie. Podle Rámcového vzdělávacího programu pro gymnázia je „školní vzdělávací program povinnou součástí dokumentace školy a musí být zveřejněn na přístupném místě“ (RVP G, 2007: s. 85). Školy tedy podle RVP G nemají povinnost zveřejňovat ŠVP na svých webových stránkách, postačující je jeho dostupnost v tištěné podobě, např. v kanceláři školy. Námi sestavený soubor ŠVP tak představuje dostupný výběr (Gavora, 2010; Cohen, Manion \& Morrison, 2011). Vzhledem k počtu ŠVP v našem výběru (42 \% ŠVP všech gymnázií v ČR) a zastoupení gymnázií ze všech 14 krajů ČR (viz tab. 1) je možné sestavený soubor považovat za reprezentativní, nebot nelze předpokládat, že by obsahová stránka ŠVP (např. osnovy jednotlivých vyučovacích předmětů) mohla být zásadně ovlivněna způsobem jeho dostupnosti (webové stránky školy, kancelář školy, vedení školy). ${ }^{1}$

\footnotetext{
${ }^{1} \mathrm{Na}$ základě doporučení jednoho z anonymních recenzentů př́spěvku jsme dodatečně analyzovali dle stejné metodiky deset gymnaziálních ŠVP, které nebyly volně přístupné na webových stránkách školy. Obsahová struktura těchto deseti ŠVP byla obdobná jako v případě ŠVP získaných z webových stránek školy. V rámci kategorizace učiva a očekávaných výstupů molekulární biologie a následné shlukové analýze jsme nezjistili žádné zásadní odlišnosti.
} 
Tab. 1: Počet ŚVP gymnázií z jednotlivých krajů Ceské republiky zahrnutých do analýzy a jejich procentuální podíl z celkového počtu gymnázií v daném kraji (zdroj: autoři)

\begin{tabular}{lcc}
\hline Kraj & $\begin{array}{c}\text { Počet ŠVP } \\
\text { v analýze }\end{array}$ & $\begin{array}{c}\text { Podíl z celkového } \\
\text { počtu škol v kraji }\end{array}$ \\
\hline Praha & 28 & $38,9 \%$ \\
\hline Středočeský & 12 & $32,4 \%$ \\
\hline Jihočeský & 10 & $38,5 \%$ \\
\hline Plzeňský & 3 & $20,0 \%$ \\
\hline Karlovarský & 5 & $50,0 \%$ \\
\hline Ustecký & 9 & $39,1 \%$ \\
\hline Liberecký & 8 & $57,1 \%$ \\
\hline Královéhradecký & 9 & $39,1 \%$ \\
\hline Pardubický & 6 & $28,6 \%$ \\
\hline Vysočina & 11 & $61,1 \%$ \\
\hline Jihomoravský & 18 & $43,9 \%$ \\
\hline Olomoucký & 11 & $55,0 \%$ \\
\hline Moravskoslezský & 19 & $43,2 \%$ \\
\hline Zlínský & 11 & $64,7 \%$ \\
\hline
\end{tabular}

V rámci komparativní analýzy ŠVP jsme posuzovali rozložení učiva molekulární biologie $\mathrm{v}$ jednotlivých ročnících gymnázia $\mathrm{v}$ povinných vyučovacích předmětech biologie a chemie a dále $\mathrm{v}$ navazujících volitelných vyučovacích předmětech (volitelné semináře z biologie a chemie). Hodnocení se týkalo 1. až 4. ročníku čtyřletého gymnázia a odpovídajících ročníků vyššího stupně víceletého gymnázia (obor gymnázium - kódy oborů 79-41-K/41, 79-41-K/61 a 79-41-K/81). Kromě rozložení učiva molekulární biologie do jednotlivých ročníků jsme se také zaměřili na obsahové zastoupení jednotlivých tematických okruhů molekulární biologie na úrovni učiva a očekávaných výstupů. Za tímto účelem jsme zpracovali systém deseti kategorií vzdělávacího obsahu molekulární biologie (viz tab. 2), do kterých jsme při obsahové analýze ŠVP řadili zastoupení učiva a očekávaných výstupů v jednotlivých ročnících povinných vyučovacích předmětů a dále jejich zastoupení ve volitelných vyučovacích předmětech. Kategoriální systém vychází, vzhledem k obecnosti vzdělávacího obsahu tematického okruhu genetika v RVP G, z obsahu učiva molekulární biologie v současných gymnaziálních učebnicích genetiky (Šmarda, 2003; Kočárek, 2004), které jsou dostupné na knižním trhu a využívané ve školní výuce. Obě učebnice reflektují současný stav molekulární biologie jako vědního oboru a z hlediska ontodidaktické i psychodidaktické transformace je považujeme za velice zdařilé.

Obsahová a konstruktová validita systému kategorií pro analýzu vzdělávacího obsahu molekulární biologie (viz tab. 2) byla ověřena jedním odborníkem na didaktiku biologie a jedním odborníkem v oboru molekulární biologie. Hodnotitelé posuzovali navržený systém kategorií, obsahovou náplň jednotlivých kategorií a využitelnost celého systému pro obsahovou analýzu gymnaziálních ŠVP pro tematický okruh molekulární biologie. Z hodnocení odborníků vyplynulo, že systém kategorií je jasně definovaný a pokrývá témata molekulární biologie obsažená v současných učebnicích genetiky pro gymnázia. Připomínky odborníků, týkající se pojmového obsahu deseti hlavních kategorií, byly do konečné verze kategoriálního systému zapracovány. Reliabilita navrženého systému kategorií pro obsahovou analýzu SVP na úrovni učiva a očekávaných výstupů v oblasti molekulární biologie byla ově- 
Tab. 2: Kategoriální systém pro obsahovou analýzu učiva a očekávaných výstupů ve vztahu k molekulární biologii (zdroj: autoři)

\section{Kategorie 1: Nukleové kyseliny a bílkoviny}

chemické složení živých organismů/buňky (charakteristika/funkce organických molekul), biologické makromolekuly, biomakromolekuly, nukleové kyseliny, DNA, RNA, typy RNA, bílkoviny (proteiny), charakteristika a význam prostorové struktury bílkovin, denaturace bílkovin

Kategorie 2: Molekulární biologie virů a bakterií
genofor virů, DNA/RNA viry, rozmnožování DNA/RNA virů včetně retrovirů,
charakteristika lytického a lyzogenního (virogenního) cyklu; genofor bakteriální
(prokaryotické) buňky, bakteriální chromozom, nukleoid, plazmidy, molekulární biologie
(genetika) bakteriální (prokaryotické) buňky

\section{Kategorie 3: Ústřední dogma molekulární biologie, genová exprese}

ústřední dogma molekulární biologie, charakteristika genové exprese, přenos genetické informace, replikace DNA, transkripce, translace, proteosyntéza, posttranskripční a posttranslační úpravy, genetický kód, charakteristika genu na molekulární úrovni, typy genů (strukturní geny, geny pro funkční RNA, regulační geny)

\section{Kategorie 4: Regulace genové exprese}

regulace genové exprese, regulace genové exprese na úrovni transkripce a translace, regulace genové exprese prokaryotické buňky, operonový model, lac-operon, regulace genové exprese u eukaryotických buněk

\section{Kategorie 5: Mutace}

mutace, mutageny, typy mutací, klasifikace mutací, molekulární podstata mutací, genové mutace, vliv genových mutací na genovou expresi a primární strukturu bílkovin, genomové mutace, evoluční význam mutací, geneticky podmíněná onemocnění člověka

\section{Kategorie 6: Metody molekulární biologie}

izolace (extrakce) DNA (nukleových kyselin), elektroforéza nukleových kyselin/bílkovin, restrikční analýza nukleových kyselin, polymerázová řetězová reakce (PCR), sekvenování nukleových kyselin, DNA čipy a jejich využití, hybridizace nukleových kyselin

\section{Kategorie 7: Genové inženýrství}

genové inženýrství, geneticky modifikované organismy (GMO), transgenoze, transgenní organismy, možnosti využití GMO člověkem, klonování (reprodukční, terapeutické), metody genového inženýrství, genová terapie

\section{Kategorie 8: Genomika, bioinformatika}

sekvenování lidského genomu, projekt lidského genomu, sekvenování genomu živých organismů, genomika, bioinformatika, vyhledávání informací v genových (proteinových) databázích, analýza (tvorba) fylogenetických stromů

Kategorie 9: Molekulární podstata nádorových onemocnění, onkogenetika
karcinogeny (kancerogeny), karcinogeneze (kancerogeneze), protoonkogeny, onkogeny,
poruchy buněčného cyklu, poruchy buněčného cyklu a nádorová onemocnění, př́klady
a charakteristika vybraných nádorových onemocnění
Kategorie 10: Etické aspekty molekulární biologie, legislativa a molekulární
biologie
etické aspekty molekulární biologie (etika v molekulární biologii), etické aspekty
genového inženýrství (klonování, genetických modifikací), rizika využívání GMO, etické
aspekty molekulární diagnostiky onemocnění a genové terapie, problémy a př́nosy
molekulární biologie, legislativní aspekty molekulární biologie


řena stanovením shody dvou nezávislých posuzovatelů u náhodně vybraného vzorku $10 \%$ všech ŠVP (včetně ŠVP pro volitelné předměty) zahrnutých do analýzy. Dosažená míra shody dvou posuzovatelů činila $92,3 \%{ }^{2}$. Největší rozdíly mezi hodnotiteli nastaly v případech, kdy učivo a očekávané výstupy na úrovni ŠVP nebyly v porovnání s RVP G vůbec rozpracovány (případně byly rozpracovány jen minimálně). Po sjednocení způsobu kódování hodnotitelů v těchto specifických případech činila shoda obou posuzovatelů 95,9\%. Vzhledem k vysoké shodě posuzovateli̊ při použití navrženého systému kategorií bylo kódování celého souboru analyzovaných ŠVP provedeno jedním hodnotitelem.

Kódování kategorie obsahu a ročníku gymnázia v předmětech biologie a chemie a kódování zastoupení hodnocené kategorie ve volitelném semináři z biologie a chemie (bez ohledu na název volitelného semináře v konkrétním ŠVP) bylo provedeno v programu Microsoft Excel 2010. Vytvořená datová matice byla převedena do programu STATISTICA 12, ve kterém byly zpracovány dílčí statistické analýzy. Zastoupení učiva molekulární biologie v jednotlivých ročnících studia pro předměty biologie, chemie a volitelné semináře bylo hodnoceno prostřednictvím shlukové analýzy kategoriálních dat metodou $k$-průměrů. Základní parametry shlukové analýzy byly nastaveny následovně: euklidovské vzdálenosti mezi shluky, 50 iterací a desetinásobná kř́̌žová validace pro každou z realizovaných analýz. Na shlukovou analýzu navazoval $\chi^{2}$ test nezávislosti zastoupení kategoriálních proměnných (ročníky gymnázia) v jednotlivých shlucích. Zastoupení četností jednotlivých kategorií obsahu molekulární biologie v ŠVP v rámci základní výuky (předměty biologie a chemie) a v rámci volitelných předmětů (předměty seminář z biologie a seminář z chemie) bylo analyzováno pomocí Fisherova přesného dvoustranného testu. Rozdíly mezi hodnocenými skupinami byly považovány za statisticky významné, jestliže dosažená hladina testu (p) byla menší nebo rovna zvolené $5 \%$ hladině významnosti $(p \leq 5 \%)$. Výsledky statistických analýz byly graficky zpracovány v programu SigmaPlot 13.

Pro doplnění informací získaných analýzou školních vzdělávacích programů ve školách, které vyučují v rámci volitelných předmětů seminář zaměřený na molekulární biologii (celkem 19 škol), jsme požádali vyučující příslušných seminářù o vyplnění krátkého on-line dotazníku. Dotazník byl zpracován v on-line prostředí Google Docs a obsahoval 10 otevřených otázek zaměřených na bližší údaje o volitelných seminářích z molekulární biologie. Dotazník byl administrován elektronickou formou, webový odkaz byl respondentům zaslán e-mailem po předchozí telefonické domluvě. Osloveno bylo 19 respondentů (vyučujících volitelného předmětu seminář zaměřený na molekulární biologii) z 19 gymnázií, návratnost dotazníku činila 89,5 \% (dotazník vyplnilo 17 učiteli̊, z toho 12 žen a 5 mužů).

\subsection{HODNOCENÍ POKROČILÝCH LABORATORNÍCH CVIČENÍ Z MOLEKULÁRNí BIOLOGIE ŽÁKY STŘEDNÍCH ŠKOL}

Středoškolští žáci běžných tř́d i biologicky zaměřených volitelných seminářů absolvovali molekulárně biologická laboratorní cvičení. Vyučujícím byl lektor z Přírodovědecké fakulty Univerzity Karlovy v Praze (UK PřF) nebo proškolený středoškolský učitel. Cvičení probíhala jak na půdě UK PřF, tak na středních školách žáků. Učitelé si vybírali ze čtyř různých témat laboratorních cvičení. Dvě cvičení byla založena

\footnotetext{
${ }^{2}$ Jedná se o procento shody v 780 případech kódování kategorie obsahu a ročníku gymnázia v předmětech biologie a chemie a kódování hodnocené kategorie ve volitelném semináři z biologie a chemie.
} 
na využití polymerázové řetězové reakce (PCR), díky které byla určena jedna z alel determinující Rh-faktor (dále označováno jako PCR Rh-faktor; Imperial \& Boronat, 2005), resp. (ne)přítomnost jednoho z chemokinových receptorů (dále označováno jako PCR CCR5; Falteisek, Černý \& Janštová, 2013). Třetí cvičení bylo zaměřeno na restrikční štěpení DNA bakteriálních plazmidů (dále označováno jako restrikce plazmidů) a poslední cvičení bylo zaměřeno na elektroforézu bílkovin (Janštová, Pavlasová \& Černý, 2014). Středoškolští učitelé vedli pouze dva druhy laboratorních cvičení, a to restrikci plazmidů a elektroforézu bílkovin. Bezprostředně po ukončení laboratorního cvičení byli žáci požádáni o hodnocení cvičení pomocí krátkého reflektivního dotazníku (vyplnění dotazníku trvalo maximálně 10 minut). Dotazník obsahoval 10 položek (5 otevřených položek, 1 uzavřená položka s výběrem odpovědí a 4 pětibodové Likertovy škály). Prostřednictvím položek Likertovy škály (zcela souhlasím, částečně souhlasím, neutrální postoj/nevím, částečně nesouhlasím, zcela nesouhlasím) žáci hodnotili srozumitelnost úvodního výkladu lektora, pochopení kroků postupu laboratorního protokolu, celkové provedení laboratorního cvičení a atraktivitu molekulárně biologického tématu cvičení. Split-half reliabilita položek Likertovy škály v reflektivním dotazníku činila 0,622. Vyhodnocení položek Likertovy škály bylo provedeno metodikou podle Kidmanové (2008). Odpovědi žáků byly kódovány následujícím zpo̊sobem: zcela souhlasím $=1$; částečně souhlasím $=0,5$; neutrální $\operatorname{postoj} /$ nevím $=0$; částečně nesouhlasím $=-0,5$; zcela nesouhlasím $=-1$. Tento způsob kódování umožňuje přehledné grafické porovnání souhlasných a nesouhlasných odpovědí (Kidmanová, 2008: s. 90). V otevřených otázkách žáci hodnotili, které aspekty laboratorního cvičení považovali za nejvíce a nejméně přínosné, respektive nejvíce a nejméně zajímavé. $V$ uzavřené položce $s$ výběrem odpovědí žáci porovnávali zajímavost laboratorního cvičení z molekulární biologie s běžnou laboratorní výukou na střední škole.

Pro každou skupinu hodnocených odpovědí položek na Likertově škále byl vypočten aritmetický průměr a medián. V následných statistických analýzách byl zjištován vztah mezi hodnocením laboratorního cvičení žáky a následujícími nezávislými proměnnými: typ laboratorního cvičení (viz čtyři výše uvedená témata), místo konání laboratorního cvičení (UK PřF nebo střední škola), osoba vyučujícího (lektor z vysoké školy nebo středoškolský učitel), pohlaví a ročník studia na stř̌ední škole. Pro hodnocení jsme použili vícefaktorovou analýzu rozptylu bez opakování (ANOVA hlavních efektů) s následným Tukeyovým post-hoc testem, abychom mohli určit, které kategorie se od sebe liší. Zároveň jsme data analyzovali neparametrickým Kruskal-Wallisovým testem s vícenásobným porovnáváním. Obě statistické metody ukázaly stejné statisticky významné rozdíly mezi hodnocenými faktory. Zjištěné rozdíly byly považovány za statisticky významné, jestliže dosažená hladina testu (p) byla menší nebo rovna zvolené $5 \%$ hladině významnosti $(p \leq 5 \%)$. Výsledky statistických analýz byly graficky zpracovány v programu SigmaPlot 13 .

Odpovědi na otevřené otázky (největší a nejmenší přínos laboratorního cvičení; nejzajímavější a nejméně zajímavé aspekty laboratorního cvičení) byly kódovány do následujících kategorií: (1) nové metody, přístroje a praktické vyzkoušení úlohy; (2) vlastní výsledek cvičení; (3) získání nových informací; (4) chybějící odpověd’ a nic; (5) časová náročnost cvičení; (6) vše a celé cvičení; (7) možnost uplatnit vlastní návrhy postupu a porovnat výsledek s předpoklady; (8) složitost/náročnost cvičení; (9) jiné odpovědi. Poté byly vyhodnoceny četnosti v jednotlivých kategoriích. Také u poslední otázky dotazníku, která zjištovala, jak žáky bavilo absolvované molekulárně biologické cvičení v porovnání s běžnými cvičeními ve škole a proč, byly vyhodnoceny absolutní a relativní četnosti odpovědí. 


\section{VÝSLEDKY A DISKUZE}

\subsection{ZASTOUPENÍ VZDĚLÁVACÍHO OBSAHU MOLEKULÁRNÍ BIOLOGIE NA ÚROVNI GYMNAZIÁLNÍCH ŠVP}

\subsubsection{VYUČOVACí PŘEDMĚTY BIOLOGIE A SEMINÁŘ Z BIOLOGIE}

Výsledkem shlukové analýzy zastoupení učiva a očekávaných výstupů molekulárně biologických témat $\mathrm{v}$ jednotlivých ročnících předmětu biologie na gymnáziu je rozdělení souboru analyzovaných ŠVP $(n=160)$ do 12 skupin (shluků). Základní charakteristiky jednotlivých skupin jsou shrnuty v tabulce 3 . Testem nezávislosti $\left(\chi^{2}\right.$ test) pro kategoriální proměnné (1. až 4. ročník gymnázia) byly prokázány statisticky významné rozdíly mezi jejich četnostmi v jednotlivých shlucích $(p<0,01)$.

Z výsledků analýzy vyplývá, že zařazení témat molekulární biologie do jednotlivých ročníků v rámci předmětu biologie je na úrovni gymnaziálních ŠVP velice různorodé (viz tab. 3). Nejčastěji jsou tato témata řazena do posledního ročníku (3. nebo 4. ročník), ve kterém je výuka biologie realizována (celkem $55 \%$ analyzovaných ŠVP, součet četností ve shlucích 1 a 2 ), případně do posledních dvou ročníků studia (3. a 4. ročník; celkem 3,75 \% ŠVP, shluk 5). Velmi často jsou témata z molekulární biologie také zařazena $\mathrm{v}$ prvním ročníku a následně až ve 3 . nebo 4. ročníku (celkem 31,87 \% ŠVP, součet četností ve shlucích 3 , 4 a 6).

Tab. 3: Výsledky shlukové analýzy zastoupení molekulárně biologických témat $\mathrm{v}$ jednotlivých ročnících gymnázia $\mathrm{v}$ předmětu biologie (zdroj: autoři)

\begin{tabular}{ccccccc}
\hline $\begin{array}{c}\text { Číslo } \\
\text { shluku }\end{array}$ & 1. ročník & 2. ročník & 3. ročník & 4. ročník & $\begin{array}{c}\text { Počet } \\
\text { ŠVP }\end{array}$ & $\begin{array}{c}\text { Podíl } \\
\text { z celkového } \\
\text { počtu SVP }\end{array}$ \\
\hline 1 & 0 & 0 & 0 & 1 & 45 & $28,12 \%$ \\
\hline 2 & 0 & 0 & 1 & $\times$ & 43 & $26,88 \%$ \\
\hline 3 & 1 & 0 & 1 & $\times$ & 24 & $15,00 \%$ \\
\hline 4 & 1 & 0 & 0 & 1 & 22 & $13,75 \%$ \\
\hline 5 & 0 & 0 & 1 & 1 & 6 & $3,75 \%$ \\
\hline 6 & 1 & 0 & 1 & 0 & 5 & $3,12 \%$ \\
\hline 7 & 0 & 0 & 0 & $\times$ & 4 & $2,50 \%$ \\
\hline 8 & 1 & 0 & 0 & $\times$ & 3 & $1,88 \%$ \\
\hline 9 & 1 & 1 & 0 & $\times$ & 3 & $1,88 \%$ \\
\hline 10 & 0 & 1 & 1 & 0 & 2 & $1,25 \%$ \\
\hline 11 & 0 & 1 & 1 & $\times$ & 2 & $1,25 \%$ \\
\hline 12 & 1 & 0 & $\times$ & $\times$ & 1 & $0,62 \%$ \\
\hline
\end{tabular}

Vysvětlivky číselných kódi̊: $0=v$ daném ročníku nejsou zastoupena témata z molekulární biologie; $1=v$ daném ročníku jsou zastoupena témata $z$ molekulární biologie $; \times=v$ daném ročniku neni dle S̆VP zařazen predmèt biologie

Ostatní způsoby ročníkového zařazení molekulární biologie do výuky jsou mnohem méně časté (viz shluky 8-12), např́iklad zařazení molekulární biologie jen do prvního či prvních dvou ročníků studia (celkem 4,38 \%, součet četností ve shlucích 8,9 a 12). Poměrně překvapivým zjištěním je, že $\mathrm{v}$ případě čtyř škol nebyla molekulárně biologická témata $\mathrm{v}$ rámci povinné biologie v ŠVP vůbec uvedena (viz arbitrárně vytvořený shluk 7). 
V kontextu výše uvedených empirických zjištění spatřujeme několik potenciálních problémů v zařazení molekulární biologie do posledního ročníku výuky biologie. Vzhledem k tomu, že molekulární biologie je jedním z ústředních konceptů současné biologie (viz např. Nurse, 2003; Vidal, 2009), považujeme její zařazení až na konec studia gymnaziální biologie za nevhodné. Nedostatečné osvojení molekulární biologie na počátku studia znemožňuje ve výuce jednotlivých tematických okruhů biologie uvedených v RVP G průběžně reflektovat molekulární podstatu vybraných biologických procesů či smysluplně vysvětlit současné principy taxonomie živých organismů na molekulární úrovni. Zmiňovanou skutečnost považujeme za problém nedostatečné ontodidaktické transformace obsahu biologie jako vědní disciplíny do vzdělávacího obsahu biologie jako vzdělávacího oboru (na úrovni RVP G), respektive vyučovacího předmětu na úrovni konkrétních ŠVP (srov. Janík \& Slavík, 2007). Jako př́klad zdařilé ontodidaktické transformace obsahu biologie na středoškolskou (gymnaziální) úroveň mohou sloužit mimo jiné National Science Education Standards (NSES) v USA (National Committee on Science Education Standards and Assessment \& National Research Council, 1996). Standardy vymezující vzdělávací obsah biologie (Life Science) pro středoškolské studenty (stupně vzdělávání 9-12) odrážejí současný stav biologie jako vědní disciplíny, přičemž buněčná biologie, molekulární biologie a evoluční biologie fungují jako sjednocující koncepty tvořící podstatnou část obsahových standardů (NSES, 1996, s. 181-187). Tento obecně biologický přístup jako výsledek ontodidaktické transformace obsahu biologie je zřetelný ve středoškolských učebnicích biologie v USA (viz např. Miller \& Levine, 2010). Další problém (riziko) v zařazení molekulární biologie do posledního ročníku výuky spatřujeme ve skutečnosti, že v rámci učebních osnov analyzovaných ŠVP byla molekulární biologie a genetika časově řazena většinou jako jeden z posledních tematických okruhů. Vzhledem ke značnému rozsahu učiva gymnaziální biologie tak může velice snadno nastat situace, kdy na dostatečné seznámení žáků s molekulární biologií v potřebném rozsahu nezbyde dostatek času a některé okruhy učiva a očekávané výstupy v ŠVP ve vztahu k molekulární biologii tak zůstanou pouze na úrovni projektovaného kurikula (viz kategorie projektované kurikulum II in Janík et al., 2010a: s. $33-34)$.

Kromě povinného vyučovacího předmětu biologie jsou témata z molekulární biologie do výuky řazena také v rámci volitelných seminářỏ z biologie (2. až 4. ročník). Výsledkem shlukové analýzy zastoupení molekulární biologie v jednotlivých ročnících vyučovacího předmětu seminář z biologie je rozdělení souboru analyzovaných ŠVP pro volitelné předměty $(n=106)$ do 9 shluků. Základní charakteristiky jednotlivých shluků jsou přehledně zpracovány $\mathrm{v}$ tab. 4. Test nezávislosti ( $\chi^{2}$ test) pro kategoriální proměnné (ročníky gymnázia s výukou volitelných seminářo̊) prokázal statisticky významné rozdíly mezi jejich četnostmi v jednotlivých shlucích $(p<0,01)$.

Výsledky ukazují, že většina škol v analyzovaném souboru se věnuje molekulární biologii také v rámci volitelného semináře z biologie (celkem 72,63 \% analyzovaných ŠVP, součet četností shluků $1,3,4,5$ a 7). Nejčastěji je výuka zařazena v rámci maturitního ročníku (46,23\%, součet četností shluků 1, 5 a 7$)$. Méně často je výuka zařazena do 3. a 4. ročníku (16,98 \%, shluk 3) nebo do 3. ročníku $(9,43 \%$, shluk 4). Celkem 27,37 \% škol nemá ve volitelném semináři z biologie v rámci ŠVP molekulárně biologická témata zařazena (součet četností ve shlucích 2, 6, 8 a 9). Detailní analýzou ŠVP volitelných předmětů biologického zaměření jsme zjistili, že 19 škol z analyzovaného souboru (17,92 \% ze 106 analyzovaných ŠVP) má v nabídce volitelných předmětů kromě běžného semináře z biologie také 
Tab. 4: Výsledky shlukové analýzy zastoupení molekulárně biologických témat v jednotlivých ročnících gymnázia v předmětu seminář z biologie (zdroj: autoři)

\begin{tabular}{cccccc}
\hline $\begin{array}{c}\text { Číslo } \\
\text { shluku }\end{array}$ & 2. ročník & 3. ročník & 4. ročník & $\begin{array}{c}\text { Počet } \\
\text { ŠVP }\end{array}$ & $\begin{array}{c}\text { Podíl } \\
\text { z celkového } \\
\text { počtu SVP }\end{array}$ \\
\hline 1 & $\times$ & 0 & 1 & 36 & $33,96 \%$ \\
\hline 2 & $\times$ & 0 & 0 & 22 & $20,76 \%$ \\
\hline 3 & $\times$ & 1 & 1 & 18 & $16,98 \%$ \\
\hline 4 & $\times$ & 1 & 0 & 10 & $9,43 \%$ \\
\hline 5 & $\times$ & $\times$ & 1 & 9 & $8,49 \%$ \\
\hline 6 & $\times$ & $\times$ & 0 & 4 & $3,77 \%$ \\
\hline 7 & 0 & 0 & 1 & 4 & $3,77 \%$ \\
\hline 8 & 0 & $\times$ & 0 & 2 & $1,89 \%$ \\
\hline 9 & 0 & 0 & 0 & 1 & $0,95 \%$ \\
\hline
\end{tabular}

Vysvětlivky číselných kódů: $0=v$ daném ročniku nejsou zastoupena témata $z$ molekulární biologie $; 1=v$ daném ročníku jsou zastoupena témata $z$ molekulární biologie $; \times=v$ daném ročniku neni dle ŠVP zařazen predmět seminár̆ z biologie

specializovaný seminář zaměřený na molekulární biologii a genetiku (blíže viz kapitola 4.1.2).

V rámci obsahové analýzy učiva a očekávaných výstupů jsme zjistili, že třetina škol $(34,4 \%$, celkem 55 škol) ve svých ŠVP nerozpracovala učivo ani očekávané výstupy tematického okruhu genetika z RVP G nebo je upravila naprosto minimálně (např. doplněním jednoho obecně formulovaného očekávaného výstupu nebo tématu učiva). Ačkoliv bylo možné určit, ve kterém ročníku je výuka molekulární biologie realizována, nemohli jsme $\mathrm{v}$ těchto př́padech provést detailní kategorizaci vzdělávacího obsahu molekulární biologie (viz kapitola metodika, tab. 2), protože učivo i očekávané výstupy byly formulovány prř́liš obecně (např. učivo „molekulární a buněčné základy dědičnosti“). Proto jsme kategorizaci vzdělávacího obsahu molekulární biologie mohli provést pouze u 105 ŠVP pro předmět biologie a 58 ŠVP pro předmět seminář z biologie, v nichž byly očekávané výstupy a učivo dostatečně rozpracovány z RVP G na školní úroveň.

Očekávané výstupy a rozsah učiva jednotlivých tematických celků v RVP G jsou pro školy závazné. Jak je však v RVP G uvedeno, „předpokládá se, že další nebo náročnější očekávané výstupy a širší rozsah učiva si stanoví škola sama ve svém školním vzdělávacím programu“ (RVP G, 2007: s. 12). Skutečnost, že zhruba třetina škol ve výzkumném souboru podrobněji nerozpracovala vzdělávací obsah tematického okruhu genetika a převzala jej v nezměněné či jen nepatrně upravené podobě z RVP G, může mimo jiné souviset s nízkou akceptací kurikulární reformy gymnaziálními učiteli (Janík et al., 2010b). Jak uvádí v závěrečném shrnutí výzkumné zprávy prezentující výsledky dotazníkového šetření kurikulární reformy na gymnáziích Janík et al. (2010b):

Jestliže učitelé vyhodnotí zavádění změn jako formální, pak se odmítnou do nich zapojit anebo se spíš sami chovají formálně - plní sice vnější požadavky, ale jen na „papíře“ (Janík et al., 2010b: s. 132). 


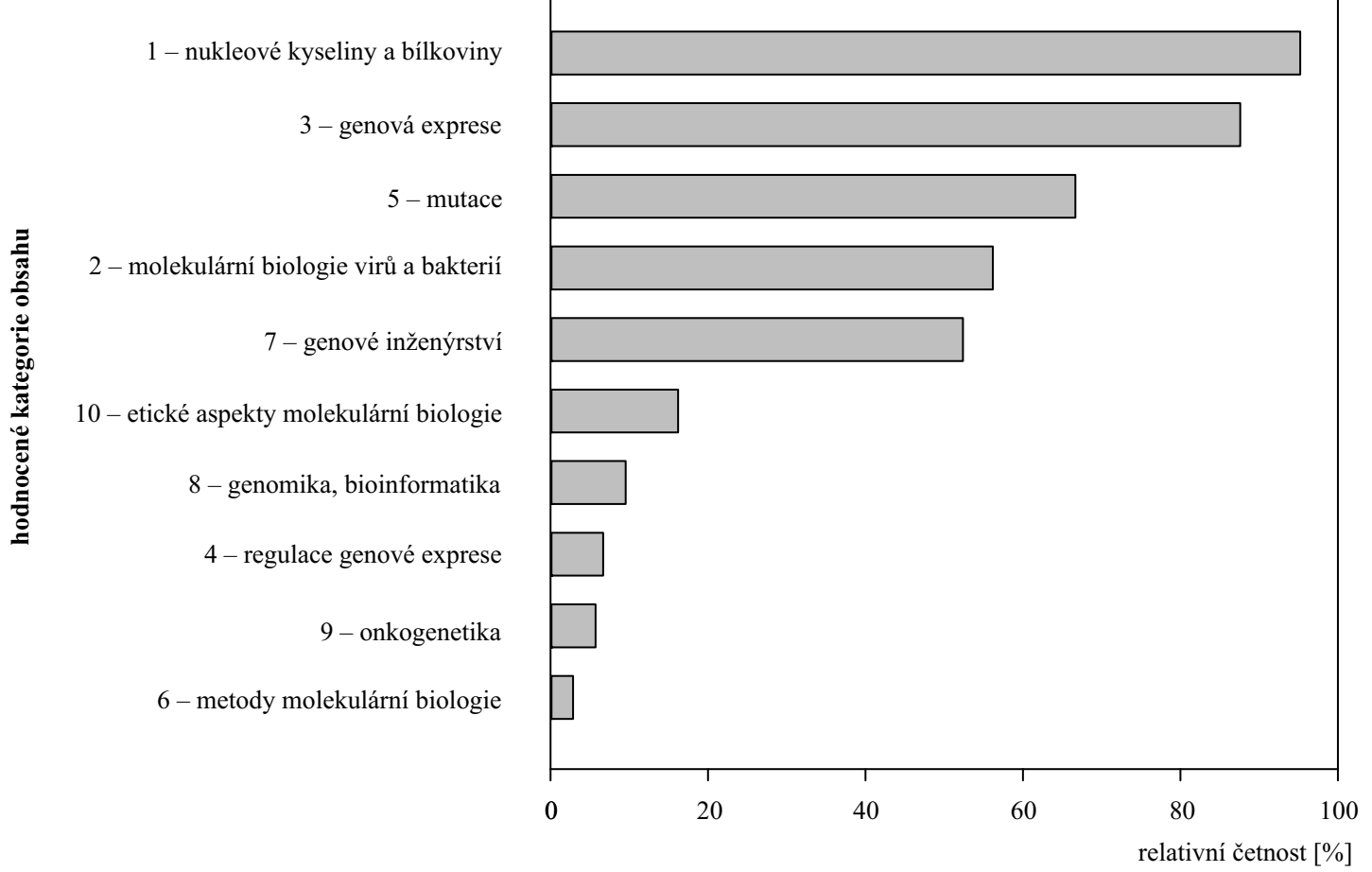

Vysvětlivky: číslice u jednotlivých témat molekulární biologie korespondují s číselným označením př́slušné kategorie $v$ tab. 2

Graf 1: Zastoupení tematických kategorií vzdělávacího obsahu molekulární biologie v ŠVP gymnázií ve vyučovacím předmětu biologie (zdroj: autoři)

Je tedy možné, že výše uvedené zjištění, na které jsme při analýze ŠVP narazili, tak může být do jisté míry odrazem formálního přístupu škol (potažmo vyučujících předmětové komise biologie na daných školách) při tvorbě ŠVP.

Zastoupení jednotlivých tematických kategorií vzdělávacího obsahu molekulární biologie na úrovni učiva a očekávaných výstupů v ŠVP v předmětu biologie přehledně znázorňuje graf 1.

Nejvíce bylo v ŠVP zastoupeno téma nukleové kyseliny a bílkoviny (95,24 \% ze 105 analyzovaných ŠVP). Toto téma bylo v ŠVP řazeno do různých ročníků studia: nejčastěji pouze do 3. nebo 4. ročníku (45,54 \% ŠVP), dále pak do 1. a 3. ročníku $(19,80$ \% ŠVP), 1. a 4. ročníku (18,81 \% ŠVP) nebo pouze do 1. ročníku $(10,89 \%$ ŠVP); jiné způsoby začlenění tématu v ŠVP tvořily 4,96 \%. Další vysoce zastoupené téma z molekulární biologie je ústřední dogma molekulární biologie a genová exprese $(87,62 \%$ ŠVP). Toto téma bylo v ŠVP zařazeno nejčastěji ve 3. nebo 4. ročníku studia (86,60 \% ŠVP). Mezi témata s vysokou četností výskytu v ŠVP patří také téma mutace $(66,67 \%$ ŠVP), téma molekulární biologie virů a bakterií $(56,19 \%$ ŠVP) a téma genové inženýrství (52,38 \% ŠVP).

Témata mutace a genové inženýrství byla zastoupena převážně ve 3 . nebo 4 . ročníku. Téma molekulární biologie virů a bakterií bylo nejčastěji zařazeno ve 3 . nebo 4. ročníku (58,06 \% ŠVP) a následně v 1. ročníku (33,87 \% ŠVP). Ostatní témata molekulární biologie byla v SVP zařazována výrazně méně často. Jedná se o následující témata: etické aspekty molekulární biologie (16,19 \% ŠVP), genomika a bioinformatika (9,52 \% ŠVP), regulace genové exprese (6,67 \% ŠVP), molekulární podstata nádorových onemocnění (5,71 \% ŠVP) a metody molekulární biologie $(2,86 \%$ ŠVP). Tato témata, pokud již byla v ŠVP uvedena, byla řazena téměř výhradně do 3 . nebo 4. ročníku studia. 


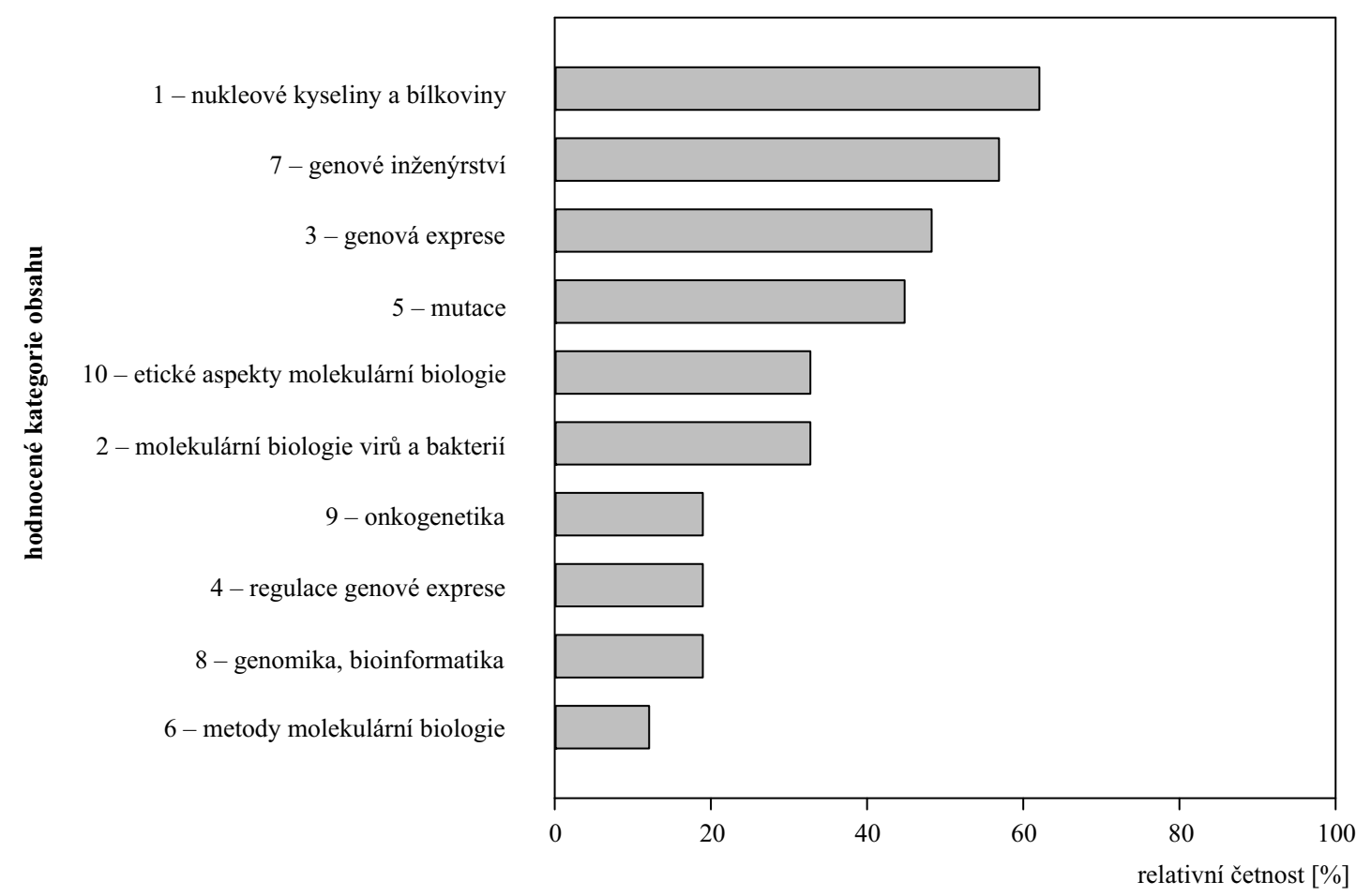

Vysvětlivky: číslice u jednotlivých témat molekulární biologie koresponduji s číselným označením př́slušné kategorie $v$ tab. 2

Graf 2: Zastoupení tematických kategorií vzdělávacího obsahu molekulární biologie v ŠVP gymnázií ve vyučovacím předmětu seminář z biologie (zdroj: autoři)

Není bez zajímavosti, že pět nejčastěji zastoupených témat bylo součástí původních osnov vyučovacího předmětu biologie (MŠMT, 1999: s. 150-156, především viz tematické celky 15 . Základní děje na buněčné úrovni a 16. Dědičnost a proměnlivost). Je tedy možné, že učitelé při př́ípravě vzdělávacího obsahu učebních osnov ŠVP do určité míry ze setrvačnosti reflektovali obsah původních osnov vyučovacího předmětu biologie. Je však nutné si uvědomit, že témata málo zastoupená v ŠVP mohou být $\mathrm{v}$ reálné výuce (realizované kurikulum) alespoň okrajově zmiňována, přičemž učitelé sestavující osnovy vyučovacího předmětu biologie nepovažovali za důležité, aby je uváděli na úrovni učiva či očekávaných výstupů.

Dále jsme zjištovali zastoupení jednotlivých tematických kategorií vzdělávacího obsahu molekulární biologie na úrovni učiva a očekávaných výstupů v ŠVP ve volitelném předmětu seminář z biologie. Výsledky analýzy shrnuje graf 2 .

Nejvíce zastoupeným je téma nukleové kyseliny a bílkoviny $(62,07 \%$ z 58 analyzovaných ŠVP). Velkou četnost mají také témata genové inženýrství (56,90\% ŠVP), ústřední dogma molekulární biologie a genová exprese (48,28 \% ŠVP) a mutace $(44,82 \%$ ŠVP). Téma molekulární biologie virů a bakterií bylo zastoupeno ve 32,76 \% ŠVP. Jedná se tedy o stejná témata jako v př́padě povinného předmětu biologie. Z porovnání četností zařazení těchto témat v ŠVP předmětů biologie a seminár z biologie Fisherovým přesným dvoustranným testem však vyplývá, že četnost témat nukleové kyseliny a bílkoviny $(p<0,00001)$, ústřední dogma molekulární biologie a genová exprese $(p<0,00001)$, mutace $(p=0,00008)$ a molekulární biologie virů a bakterií $(p=0,0298)$ je statisticky významně vyšší v povinném vyučovacím předmětu biologie, nežli ve volitelném předmětu seminář z biologie. Téma genové inženýrství je v ŠVP předmětů biologie a seminář z biologie zastoupeno stejně často, rozdíl mezi četnostmi v zařazení do ŠVP není statisticky signifikantní $(p=1,0)$. Zbý- 
vající témata jsou v ŠVP předmětu seminář z biologie zastoupena méně často: téma etické aspekty molekulární biologie je reflektováno ve 32,76 \% analyzovaných ŠVP, témata genomika a bioinformatika, regulace genové exprese a molekulární podstata nádorových onemocnění jsou zastoupena v 18,97 \% ŠVP, nejméně je pak zastoupeno téma metody molekulární biologie ve 12,07 \% analyzovaných ŠVP. Porovnání četností zařazení těchto témat v ŠVP předmětů biologie a seminář z biologie poukazuje na skutečnost, že témata etické aspekty molekulární biologie $(p=0,04845)$, regulace genové exprese $(p=0,03485)$, molekulární podstata nádorových onemocnění $(p=0,01842)$ a metody molekulární biologie $(p=0,04384)$ jsou více zastoupena v ŠVP volitelného předmětu seminář z biologie. Téma genomika a bioinformatika je $\mathrm{v}$ obou sledovaných předmětech zařazeno stejně často $(p=0,1431)$. V rámci obsahové analýzy ŠVP pro předměty biologie a seminář z biologie nebylo možné hodnotit tematické zaměření a četnost případných laboratorních cvičení z molekulární biologie, protože informace týkající se témat laboratorních cvičení z biologie nebyly v naprosté většině ŠVP uváděny.

Rozdílné zastoupení molekulárně biologických témat v předmětech biologie a seminář z biologie bylo možné na jednu stranu očekávat, protože jak většina škol ve svých ŠVP deklaruje, volitelný předmět seminář z biologie je určen zejména pro žáky s velkým zájmem o obor a slouží jako příprava k maturitní zkoušce a $\mathrm{k}$ přijímacím zkouškám z biologie na VŠ. Na druhou stranu se domníváme, že některá témata by v současnosti měla být v povinné výuce biologie zastoupena výrazně více. Jedná se např́klad o problematiku metod molekulární biologie (např. ve vztahu k lékařské diagnostice dědičných onemocnění), molekulární podstatu nádorových onemocnění (vzhledem $\mathrm{k}$ celosvětově vysokému výskytu těchto onemocnění), ale zejména pak o téma etické aspekty molekulární biologie. Jak uvádí Papáček (2010):

Biologie tak nabývá stále většího významu pro každodenní společenskou praxi, a to zdaleka ne pouze v oblasti lidského zdraví a zdrojů potravin. Navíc se stává horkou arénou veřejných diskusí. Např. o geneticky modifikovaných organismech, o klonování, o umělém oplození, o oteplování a ekologické krizi či o existenci evoluce a kreacionismu. (Papáček, 2010: s. 38).

Právě proto se domníváme, že etické aspekty molekulární biologie a genetiky by měly být nedílnou součástí povinné výuky biologie a zcela určitě by se tato problematika měla objevit v ŠVP v očekávaných výstupech.

\subsubsection{VOLITELNÉ SEMINÁŘE SPECIALIZOVANÉ NA VÝUKU MOLEKULÁRNí BIOLOGIE}

Jak jsme se již zmínili v kapitole 4.1.1, poměrně zajímavým výsledkem komparativní analýzy bylo zjištění, že devatenáct škol z analyzovaného souboru $(17,9 \%)$ má ve svém ŠVP zařazený specializovaný seminář tematicky zaměřený na molekulární biologii a genetiku. Ve třech př́padech jsme neměli k dispozici osnovy tohoto předmětu, ve dvou případech byl vzdělávací obsah semináře formulován příliš obecně a nebylo možné ho kategorizovat. V ostatních čtrnácti případech však bylo zřejmé výrazné zastoupení témat, která jsou v rámci běžné výuky biologie reflektována minimálně. V osnovách specializovaných seminářů tak byla v 92,9 \% zastoupena problematika genového inženýrství, v 50 \% témata etické aspekty molekulární biologie a regulace genové exprese a ve 42,9 \% ŠVP byla zařazena témata metody molekulární biologie, 
genomika a bioinformatika a molekulární podstata nádorových onemocnění. Celkem pět ŠVP obsahovalo alespoň osm z deseti posuzovaných kategorií obsahu molekulární biologie. Specializovaný seminář byl vždy zařazen v maturitním ročníku, ve čtyřech případech byl seminář zařazen i v nižších ročnících (3. ročník a v jednom případě i 2. ročník).

Protože ze školního vzdělávacího programu nebylo obvykle možné zjistit detailnější informace o výuce tohoto předmětu, oslovili jsme učitele příslušných specializovaných seminářo̊ s žádostí o poskytnutí doplňujících informací (viz kapitola 3.1).

Jako hlavní důvody, které vedly k zavedení specializovaného semináře ve škole, uváděli učitelé $(n=17)$ nejčastěji nedostatek času na výuku molekulární biologie a genetiky v rámci běžné výuky biologie (31,6 \% respondentů) a dále pak důležitost oboru pro pochopení základních biologických zákonitostí, zájem žáků o obor a vysoké zastoupení témat $\mathrm{z}$ molekulární biologie $\mathrm{v}$ přijímacích zkouškách na vysoké školy (26,3\% respondentů). Zájem o takto koncipovaný seminář je ze strany žáků značný. Údaje z jednotlivých škol za poslední tři školní roky (2011/2012 až 2013/2014) ukazují, že specializovaný seminář v průměru navštěvovala necelá čtvrtina studentů maturitního ročníku (průměr 23,9 \%, směrodatná odchylka 9,1 \%, rozpětí hodnot z jednotlivých škol od 11,4 \% do 47,2 \%). Z pohledu zabezpečení výuky je důležité, že se na 58,8 \% škol podílí na výuce semináře více učitelů (výuka semináře tedy není většinou postavena jen na jednom vyučujícím s odborným zaměřením na molekulární biologii). Na výuce se nejvíce podílejí učitelé, kteří studovali obory biologie - chemie $(44,4 \%$ ), významně zastoupeny jsou však také ostatní běžné kombinace oborů (biologie-matematika, biologie-tělesná výchova, biologie-zeměpis a absolventi odborné biologie s pedagogickým minimem).

Významnou součástí efektivní výuky molekulární biologie jsou laboratorní cvičení a podpora rozvoje praktických dovedností v oblasti bioinformatiky (viz kapitola 2). Z tohoto důvodu nás zajímalo, zda a do jaké míry realizují učitelé tyto výukové aktivity $\mathrm{v}$ rámci specializovaných seminářů zaměřených na molekulární biologii. Laboratorní cvičení pravidelně zařazují na zhruba třech čtvrtinách škol, přičemž nejběžnější úlohou je extrakce DNA z různých zdrojů (napřr. cibule, kiwi, buňky bukální sliznice). Náročnější úlohy, k jejichž realizaci je potřeba méně dostupné technické vybavení, se ve školách snaží realizovat ve spolupráci s vysokými školami (41,2 \% škol) nebo s Akademií věd ČR (jedna škola). Jedná se např́klad o restrikční analýzu DNA, elektroforézu nukleových kyselin a bílkovin či PCR. Učitelé uváděli, že největší překážkou pro větší zastoupení laboratorních cvičení je nedostatečné technické vybavení ve školách (70,6 \% respondentů) a nedostatek času pro zařazování časově náročnějších úloh (41,2 \% respondentů). Úlohy zaměřené na bioinformatiku realizují pouze ve 3 školách (jeden respondent uvažuje o jejich zavedení poté, co absolvoval specializované školení; viz kapitola 2, Wood \& Gebhardt, 2013). V tomto kontextu učitelé nejčastěji uváděli jako limitující faktory nedostatek metodických materiálů do gymnaziální výuky (33\% respondentů), nedostatečné znalosti v oblasti bioinformatiky $(17,6 \%)$, obtížnou orientaci v rychle se vyvíjejících genových databázích $(17,6 \%$ ) a obtížný přístup do počítačové učebny ve škole, potažmo absence žákovských počítačů v odborné učebně biologie (17,6 \% respondentů). Výše uvedené údaje naznačují, že by bylo vhodné pro podporu výuky bioinformatiky ve školách realizovat podobné kurzy pro středoškolské učitele biologie, jako je tomu v zahraničí (Wood \& Gebhardt, 2013).

Za zajímavé zjištění také považujeme, že na jednom z gymnázií (Gymnázium, třída Kapitána Jaroše 14, Brno) je volitelný seminář „Molekulární biologie“ víceletý (od 2. do 4. ročníku). Výuka semináře má dlouhou tradici (od školního roku 
2000/2001), přičemž od školního roku 2009/2010 je z předmětu „Molekulární biologie" možné maturovat. Sylabus předmětu a maturitní témata zcela pokrývají současnou molekulární biologii, zastoupeno je všech deset analyzovaných tematických kategorií (Vařejka, 2012).

Skutečnost, že tyto školy nejsou schopny zařadit do běžné výuky celý rozsah učiva molekulární biologie, který považují pro rozvoj žákovských znalostí a dovedností v biologii za důležitý, může opět poukazovat na nedostatečnou ontodidaktickou transformaci obsahu biologie do kurikulárních dokumentů. Jak uvádí Papáček (2010):

„V př́ipadě vzdělávání v oblasti natolik dynamického oboru, jakým je biologie, je pak velmi užitečné alespoň kontrolně periodicky redefinovat standardy učiva pro 2. a 3. stupeň vzdělávání, a tím i periodicky zpřesňovat ŠVP a vyhodnocovat jejich akcenty." (Papáček, 2010: s. 39).

Je tedy otázkou, zda současná podoba biologického kurikula na gymnáziích, např. právě ve vztahu k molekulární biologii, plně reflektuje aktuální stav poznání v biologii jako vědním oboru a zda by nebylo vhodné ji revidovat.

\subsubsection{VyuČOVACí PŘEDMĚTy CHEMIE A SEMINÁŘ Z CHEMIE}

Výsledkem shlukové analýzy zastoupení učiva a očekávaných výstupů molekulárně biologických témat $\mathrm{v}$ jednotlivých ročnících předmětu chemie na gymnáziu je rozdělení souboru analyzovaných ŠVP $(n=160)$ do šesti shluků (viz tab. 5). Test nezávislosti ( $\chi^{2}$ test) pro kategoriální proměnné (1. až 4. ročník gymnázia) prokázal statisticky významné rozdíly mezi jejich četnostmi v jednotlivých shlucích $(p<0,01)$.

Tab. 5: Výsledky shlukové analýzy zastoupení molekulárně biologických témat v jednotlivých ročnících gymnázia v předmětu chemie (zdroj: autoři)

\begin{tabular}{cccccrc}
\hline $\begin{array}{c}\text { Číslo } \\
\text { shluku }\end{array}$ & 1. ročník & 2. ročník & 3. ročník & 4. ročník & $\begin{array}{c}\text { Počet } \\
\text { ŠVP }\end{array}$ & $\begin{array}{c}\text { Podíl } \\
\text { z celkového } \\
\text { počtu SVP }\end{array}$ \\
\hline 1 & 0 & 0 & 1 & $\times$ & 117 & $73,13 \%$ \\
\hline 2 & 0 & 0 & 0 & 1 & 24 & $15,00 \%$ \\
\hline 3 & 0 & 0 & 1 & 1 & 11 & $6,87 \%$ \\
\hline 4 & 0 & 0 & 1 & 0 & 5 & $3,13 \%$ \\
\hline 5 & 0 & 1 & 0 & 1 & 2 & $1,25 \%$ \\
\hline 6 & $\times$ & 0 & 0 & 1 & 1 & $0,62 \%$ \\
\hline
\end{tabular}

Vysvětlivky číselných kódů: $0=v$ daném ročníku nejsou zastoupena témata z molekulární biologie; $1=v$ daném ročníku jsou zastoupena témata $z$ molekulární biologie; $\times=v$ daném ročníku neni dle ŠVP zařazen predmět chemie

Výsledky shlukové analýzy ukazují, že ve většině případů jsou molekulárně biologická témata zařazena $\mathrm{v}$ osnovách předmětu chemie ve 3. ročníku studia (celkem $76,26 \%$ ŠVP, součet četností ve shlucích 1 a 4) nebo ve 4. ročníku studia (celkem $15,62 \%$ ŠVP, součet četností ve shlucích 2 a 6). V některých ŠVP (shluk 3; 6,87 \% ŠVP) byla témata z molekulární biologie zařazena jak ve 3., tak ve 4. ročníku nebo ve 2 . a 4. ročníku (shluk $5 ; 1,25 \%$ ŠVP). 
Téměř výhradně se tedy jedná o zařazení témat z molekulární biologie do posledního ročníku výuky chemie (více než 88 \% analyzovaných ŠVP), což pravděpodobně souvisí s obsahovou návazností tematických okruhů obecná chemie, anorganická chemie, organická chemie a biochemie na úrovni RVP (RVP G, 2007: s. 29-31).

Také $\mathrm{v}$ př́padě chemie je výuka molekulárně biologické problematiky zařazena do volitelného předmětu seminář z chemie. Výsledkem shlukové analýzy zastoupení molekulární biologie v jednotlivých ročnících vyučovacího předmětu seminář z chemie je rozdělení souboru analyzovaných ŠVP pro volitelné předměty $(n=108)$ do osmi shluků (viz tab. 6). Test nezávislosti ( $\chi^{2}$ test) pro kategoriální proměnné (ročníky gymnázia s výukou volitelných seminářů) prokázal statisticky významné rozdíly mezi jejich četnostmi v jednotlivých shlucích $(p<0,01)$.

Tab. 6: Výsledky shlukové analýzy zastoupení molekulárně biologických témat v jednotlivých ročnících gymnázia v předmětu seminář z chemie (zdroj: autoři)

\begin{tabular}{cccccc}
\hline $\begin{array}{c}\text { Číslo } \\
\text { shluku }\end{array}$ & 2. ročník & 3. ročník & 4. ročník & $\begin{array}{c}\text { Počet } \\
\text { ŠVP }\end{array}$ & $\begin{array}{c}\text { Podíl } \\
\text { z celkového } \\
\text { počtu ŠVP }\end{array}$ \\
\hline 1 & $\times$ & 0 & 1 & 48 & $44,44 \%$ \\
\hline 2 & $\times$ & $\times$ & 1 & 19 & $17,59 \%$ \\
\hline 3 & $\times$ & 0 & 0 & 19 & $17,59 \%$ \\
\hline 4 & $\times$ & 1 & 1 & 8 & $7,41 \%$ \\
\hline 5 & $\times$ & $\times$ & 0 & 8 & $7,41 \%$ \\
\hline 6 & $\times$ & 1 & 0 & 4 & $3,70 \%$ \\
\hline 7 & 0 & 0 & 1 & 1 & $0,93 \%$ \\
\hline 8 & 0 & 0 & $\times$ & 1 & $0,93 \%$ \\
\hline
\end{tabular}

Vysvětlivky číselných kódů: $0=v$ daném ročníku nejsou zastoupena témata z molekulární biologie; $1=v$ daném ročníku jsou zastoupena témata $z$ molekulárni biologie $; \times=v$ daném ročniku neni dle ŠV zařazen předmět seminár z chemie

Ze zjištěných výsledků vyplývá, že většina škol má v osnovách ŠVP předmětu seminář z chemie okruhy témat z molekulární biologie (celkem 74,07 \%, součet četností ve shlucích $1,2,4,6$ a 7 ). Tato témata jsou zařazena převážně ve 4 . ročníku (viz shluky 1, 2 a 7). Přibližně čtvrtina ŠVP (25,93 \%; součet četností ve shlucích 3,5 a 8 ) učivo ani školní očekávané výstupy ve vztahu k molekulární biologii neobsahovala.

V rámci obsahové analýzy učiva a očekávaných výstupů jsme zjistili, že tematické zaměření je v předmětu chemie výrazně užší než v případě předmětu biologie. Učivo v osnovách ŠVP zahrnuje dva významné tematické okruhy. Prvním je téma nukleové kyseliny a bílkoviny, které bylo obsaženo v 97,5 \% ze 160 analyzovaných ŠVP (ve čtyřech případech nebylo z formulace učiva a očekávaných výstupů zřejmé, zda je učivo ve výuce skutečně zařazeno). Druhým hlavním tématem je ústřední dogma molekulární biologie a genová exprese, které jsme zaznamenali v $65 \%$ ŠP.

Ve zbývajících 35 \% ŠVP nebylo možné, vzhledem k obecnosti formulací učiva a očekávaných výstupů, objektivně určit, zda je toto téma ve výuce skutečně zařazeno (např. učivo „metabolismus př́rodních látek“ nebo očekávaný výstup „„̌̌ák charakterizuje hlavní metabolické procesy"). Tato skutečnost odráží podobně jako v případě biologie fakt, že při tvorbě daných ŠVP byly pouze přejaty formulace z RVP G nebo byly použity formulace velmi obecné. Kromě dvou výše uvedených témat bylo na úrovni učiva či očekávaných výstupů významněji zastoupeno téma mutace $(8,12$ \% ŠVP). Ostatní témata nebyla zastoupena vůbec nebo jen v jed- 
nom případě (regulace genové exprese, genové inženýrství). Také v osnovách ŠVP pro volitelný předmět seminář z chemie byla zastoupena témata nukleové kyseliny a bílkoviny (60,19 \% ŠVP) a ústřední dogma molekulární biologie (40,74 \% ŠVP), nicméně přibližně ve čtvrtině př́ípadů nebylo opět možné vzdělávací obsah předmětu objektivně kategorizovat (viz výše). Z ostatních tematických kategorií bylo ve dvou ŠVP zařazeno téma metody molekulární biologie, ostatní témata nebyla zařazena vůbec nebo jen v jednom př́ípadě.

V rámci obsahové analýzy ŠVP pro předměty chemie a seminář z chemie nebylo možné hodnotit tematické zaměření a četnost př́ipadných laboratorních cvičení z molekulární biologie, protože informace o tématech laboratorních cvičení obecně nebyly v naprosté většině ŠVP uváděny.

\subsection{HODNOCENÍ POKROČILÝCH LABORATORNÍCH CVIČENí Z MOLEKULÁRNí BIOLOGIE ŽÁKY STŘEDNÍCH ŠKOL}

V letech 2011-2013 se jednoho z výše zmíněných laboratorních cvičení (viz kapitola 3.2) zúčastnilo přes 600 žáků středních škol. Z tohoto počtu celkem 466 žáků z 19 gymnázií a 3 středních škol (obory zdravotnické lyceum, zdravotní asistent a veterinářství) z různých krajů ČR (143 chlapců, 320 děvčat, 3 respondenti neoznačili pohlaví) vyplnilo reflektivní dotazník. Více jak polovina žáků $(n=255)$ byla ze čtvrtého ročníku, 200 žáků bylo ze třetího ročníku, 9 žáků z druhého ročníku a dva respondenti ročník studia neuvedli. Nejčastěji absolvované praktické cvičení bylo PCR CCR5 ( $n=206$ žáků), následované cvičeními restrikce plazmidů ( $n=122$ žáků) a PCR Rh-faktor ( $n=113$ žáků). Laboratorního cvičení zaměřeného na elektroforézu bílkovin se zúčastnilo 25 žáků. Na středních školách absolvovalo cvičení 284 žáků. Pro 82 z nich vedl laboratorní cvičení proškolený středoškolský učitel, zbylá cvičení vedl lektor UK PřF ( $n=202$ žáků). Vysokoškolský lektor vedl i cvičení provedená na UK PřF ( $n=182$ žáků). Všechna čtyři praktická cvičení byla na Likertově škále hodnocena $\mathrm{v}$ jednotlivých sledovaných parametrech vysoce pozitivně (viz tab. 7). Průměrné hodnoty hodnocení se pohybovaly v rozmezí 1 (zcela souhlasím) a 0,5 (částečně souhlasím), viz tab. 7 a graf 3 .

V některých sledovaných parametrech byly u jednotlivých laboratorních cvičení zjištěny statisticky signifikantní rozdíly (viz graf 3 ). Pochopení kroků pracovního postupu a atraktivita tématu byly žáky vnímány hưře u cvičení zaměřeného na restrikci plazmidů v porovnání se cvičením PCR CCR5 (výsledek Tukeyova posthoc testu: $p=0,0003)$.

Tab. 7: Hodnocení pokročilých laboratorních cvičení z molekulární biologie žáky středních škol (zdroj: autoři)

\begin{tabular}{lc|ccc|cc}
\hline $\begin{array}{l}\text { Laboratorní } \\
\text { cvičení }\end{array}$ & \multicolumn{3}{c}{ Průměrné skóre hodnocení $\mid$ medián hodnocení } \\
\cline { 2 - 6 } & Atraktivita & Provedení & Pochopení & Srozumitelnost \\
\hline PCR CCR5 & $0,74 \mid 0,5$ & $0,77 \mid 1,0$ & $0,73 \mid 0,5$ & $0,74 \mid 0,5$ \\
\hline PCR Rh-faktor & $0,74 \mid 1,0$ & $0,76 \mid 1,0$ & $0,65 \mid 0,5$ & $0,63 \mid 0,5$ \\
\hline Restrikce plazmidů & $0,55 \mid 1,0$ & $0,72 \mid 1,0$ & $0,53 \mid 0,5$ & $0,75 \mid 0,5$ \\
\hline Elektroforéza bílkovin & $0,80 \mid 0,5$ & $0,70 \mid 0,5$ & $0,62 \mid 0,5$ & $0,84 \mid 0,5$ \\
\hline
\end{tabular}

Vysvětlivky: Hodnocena byla atraktivita tématu, celkové provedení laboratorního cvičení, pochopeni kroku laboratorního protokolu a srozumitelnost úvodního výkladu lektora (viz zkrácená označení sledovaných faktorů v záhlaví sloupců 2 až 5 tabulky). Hodnoty v tabulce udávají průměrné skóre hodnocení (první hodnota) a medián hodnocení (druhá hodnota). 


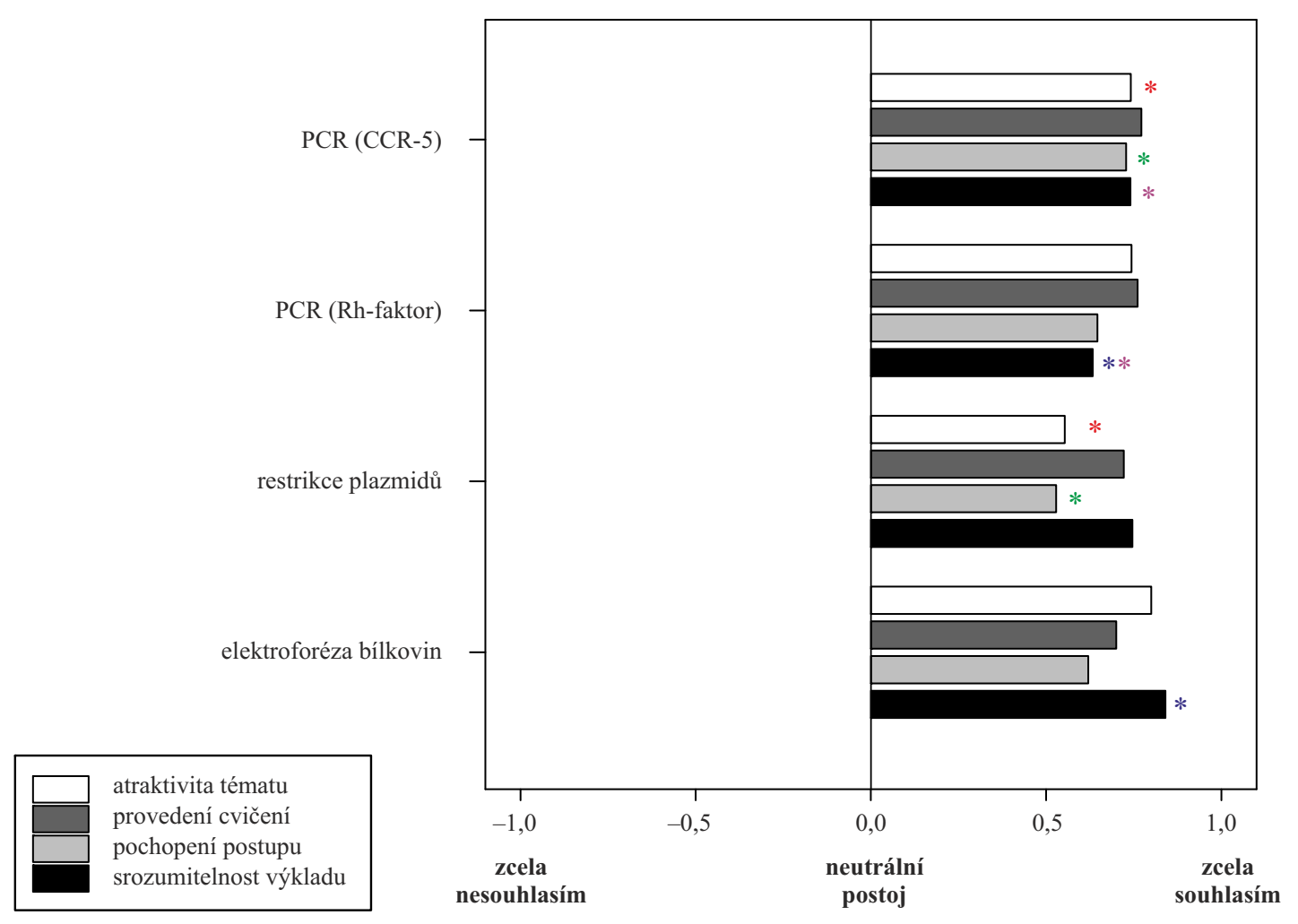

Graf 3: Vliv typu laboratorního cvičení z molekulární biologie na žákovské hodnocení atraktivity tématu, celkového provedení cvičení, pochopení kroků laboratorního postupu a srozumitelnosti úvodního výkladu lektora. Každý sloupec představuje průměrné hodnocení daného faktoru na Likertově škále. Signifikantní rozdíly mezi faktory, popsané v textové části, jsou označeny barevnými hvězdičkami

To může být dáno i tím, že při laboratorním cvičení zaměřeném na restrikci plazmidů měli žáci možnost zvolit si svoji kombinaci dostupných restrikčních enzymů, a tedy svůj způsob řešení. Na správnosti jejich volby závisela jejich úspěšnost. I když řada prací poukazuje na vhodnost dát žákům možnost volby postupu laboratorního cvičení, a vyučovat tedy podle zásad badatelsky orientované výuky (viz např. Costenson \& Lawson, 1986; German, 1996; Papáček, 2010), žáci, kteří absolvovali badatelsky orientovanou výuku, mohou své laboratorní schopnosti hodnotit hưře než žáci, kteří stejné téma absolvovali podle tradičního způsobu výuky (Gormally et al., 2009). Je tedy možné, že vy̌šśi požadavky na návrh vlastního řešení úlohy (výběr restrikčních enzymů) negativně ovlivnily bezprostřední hodnocení laboratorních cvičení. Je potřeba uvažovat i další možné přičiny tohoto rozdílu v hodnocení laboratorních cvičení, jako např́íklad možnou rozdílnou úroveň ontodidaktické transformace obsahu, správnost volby cílů a prostředků $\mathrm{k}$ jejich dosažení. Jak shrnuje van den Berg (2013), tyto faktory mají na dosažení vzdělávacího cíle zásadní vliv. Tyto případné rozdíly jsme minimalizovali tím, že se na př́pravě cvičení podíleli titíž odborníci a všechna laboratorní cvičení byla pilotně oveřena. $\mathrm{V}$ hodnocení celkového provedení cvičení (logická návaznost kroků) nebyly zjištěny statisticky významné rozdíly. Srozumitelnost úvodního výkladu lektora byla signifikantně nižší u cvičení PCR Rh-faktor v porovnání se cvičeními PCR CCR $(p=0,01)$ a elektroforéza bílkovin $(p=0,008)$, jak je zřejmé z grafu 3 . Hodnocení srozumitelnosti úvodního výkladu lektora se lišilo i mezi žáky třetího a čtvrtého ročníku $(p=0,004)$, přičemž nové teorii více rozuměli žáci čtvrtého ročníku. To lze vysvětlit tím, že cvičení PCR Rhfaktor nejvíce absolvovali žáci třetího ročníku pod vedením vysokoškolského lektora (viz dále), přičemž se tito žáci v běžné výuce ještě nesetkali se základy molekulární 


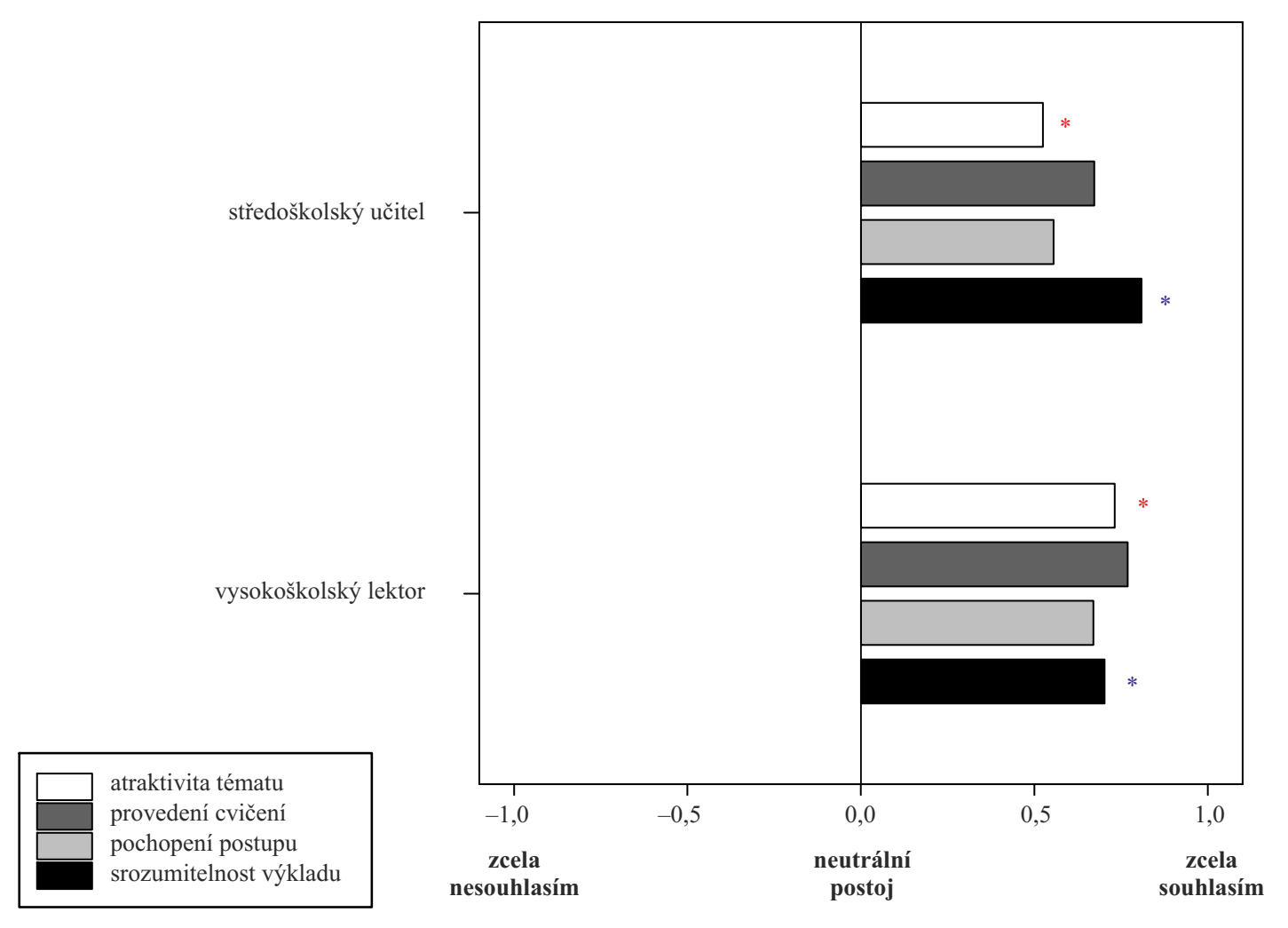

Graf 4: Vliv vyučujícího na žákovské hodnocení molekulárně biologických laboratorních cvičení. Každý sloupec představuje průměrné hodnocení daného faktoru na Likertově škále. Signifikantní rozdíly mezi faktory, popsané v textové části, jsou označeny barevnými hvězdičkami

biologie a genetiky ani s problematikou krevních skupin v rámci biologie člověka. Můžeme tedy vyvodit doporučení, aby molekulárně biologická laboratorní cvičení žáci absolvovali až po teoretickém úvodu ve výuce biologie. Ostatní hodnocené faktory se mezi ročníky statisticky významně nelišily (pochopení kroků laboratorního postupu: $p=0,30$; celkové provedení laboratorního cvičení: $p=0,93$; atraktivita tématu: $p=0,76)$. $\mathrm{V}$ hodnocení laboratorních cvičení nebyl statisticky významný rozdíl mezi chlapci a děvčaty $\mathrm{v}$ žádném ze sledovaných parametrů $(p=0,1)$. Laboratorní cvičení byla hodnocena signifikantně rozdílně ve všech čtyřech faktorech v závislosti na místě provedení cvičení (střední škola vs. UK PřF). Pokud byla cvičení provedena na UK PřF, byla hodnocena jako lépe srozumitelná (výsledek Tukeyova post-hoc testu: $p=0,001)$, žáci lépe chápali kroky laboratorního postupu $(p=0,01)$, lépe hodnotili celkové provedení cvičení $(p=0,007)$ a celkovou atraktivitu tématu $(p=0,0004)$. Je možné, že na žáky pozitivně působilo vysokoškolské prostředí a více cvičení „prožívali“, protože probíhala v jiném kontextu. Průměrné hodnoty se pohybovaly v rozmezí 1 (zcela souhlasím) a 0,5 (částečně souhlasím).

Osoba vyučujícího, tj. středoškolský učitel či vysokoškolský lektor, ovlivnila hodnocení některých aspektů vnímání laboratorního cvičení. Statisticky významný rozdíl nebyl zjištěn $\mathrm{v}$ míře pochopení kroků laboratorního postupu ani celkovém provedení laboratorního cvičení. Ve zbylých charakteristikách byly rozdíly statisticky signifikantní. Pokud vedl laboratorní cvičení stř̌edoškolský učitel, žáci lépe hodnotili srozumitelnost úvodního výkladu $(p=0,004)$, naopak atraktivita cvičení byla hodnocena lépe pod vedením vysokoškolského lektora $(p=0,0004)$, viz graf 4 . Nabízí se vysvětlení, že úvodní výklad středoškolského učitele byl hodnocen jako srozumitelnější, protože učitel přesně věděl, na které znalosti může navázat a odkázat. 
Zároveň, jak bylo zmíněno výše, lektor vedl cvičení PCR Rh-faktor pro třetí ročníky, ve kterých neměli žáci základní znalosti molekulární biologie. Další faktor, který toto hodnocení mohl ovlivnit, je, že středoškolští učitelé nevedli všechny typy laboratorních cvičení, ale pouze restrikci plazmidů, u které byla atraktivita cvičení nejnižší, a elektroforézu bílkovin. To bylo dáno možnostmi provedení laboratorních cvičení pod vedením učitelů.

Zajímavým zjištěním je, že tři nejpřínosnější aspekty laboratorních cvičení žáci zároveň hodnotili jako nejzajímavější (sestupně: nové metody; vlastní výsledek cvičení; získání nových informací), stejně tak tři nejméně přínosné faktory byly zároveň vnímány jako nejméně zajímavé (sestupně: nic, tj. vše bylo zajímavé/př́ínosné; časová náročnost cvičení; jiné odpovědi), viz tab. 8. Žáci nejkladněji hodnotili možnost vyzkoušet si v praxi laboratorní metody, o kterých dosud slyšeli jen teoreticky. Většina respondentů neuvedla žádný negativní aspekt, nejčastěji byla záporně hodnocena časová náročnost cvičení (zhruba čtyři hodiny). Pokud byl výsledek cvičení zmíněn jako negativní aspekt, bylo to proto, že tito respondenti nemohli výsledek laboratorních cvičení jednoznačně vyhodnotit.

Tab. 8: Četnosti odpovědí žáků na otázky zjištující nejvíce a nejméně př́inosné, resp. nejvíce a nejméně zajímavé, aspekty laboratorních cvičení. Buňky tabulky, obsahující tři nejčetnější kategorie pro každou otázku, jsou podbarveny šedě

\begin{tabular}{|c|c|c|c|c|}
\hline Kategorie & $\begin{array}{c}\text { Četnost } \\
\text { nejpř́ínosnější }\end{array}$ & $\begin{array}{l}\text { Četnost } \\
\text { nejméně } \\
\text { přínosné }\end{array}$ & $\begin{array}{c}\text { Četnost } \\
\text { nejzajímavějši }\end{array}$ & $\begin{array}{l}\text { Četnost } \\
\text { nejméně } \\
\text { zajímavé }\end{array}$ \\
\hline $\begin{array}{l}\text { (1) nové metody, nové } \\
\text { přístroje, praktické } \\
\text { vyzkoušení úlohy }\end{array}$ & 153 & 25 & 214 & 27 \\
\hline $\begin{array}{l}\text { (2) vlastní výsledek } \\
\text { cvičení }\end{array}$ & 119 & 15 & 113 & 8 \\
\hline $\begin{array}{l}\text { (3) získání nových } \\
\text { informací }\end{array}$ & 116 & 31 & 49 & 43 \\
\hline $\begin{array}{l}\text { (4) nic/chybějící } \\
\text { odpověd' }\end{array}$ & 40 & 274 & 45 & 262 \\
\hline $\begin{array}{l}\text { (5) časová náročnost } \\
\text { cvičení }\end{array}$ & 0 & 54 & 0 & 54 \\
\hline (6) vše/celé cvičení & 22 & 1 & 24 & 0 \\
\hline $\begin{array}{l}\text { (7) možnost uplatnit } \\
\text { vlastní návrhy } \\
\text { postupu }\end{array}$ & 4 & 2 & 8 & 2 \\
\hline $\begin{array}{l}\text { (8) } \\
\text { složitost/náročnost } \\
\text { cvičení }\end{array}$ & 0 & 18 & 0 & 16 \\
\hline (9) jiné odpovědi & 12 & 46 & 13 & 54 \\
\hline
\end{tabular}

Poznámka: úplné znění posuzovaných kategorií - viz kapitola 3.2.

V porovnání s běžnými laboratorními cvičeními ve škole 421 žáků více bavilo molekulárně biologické cvičení. Většina uvedla, že hlavním důvodem byla možnost vyzkoušet si práci s vybavením, které ve škole nemají k dispozici. Méně často se vyskytly důvody jiný vyučující a prostředí vysoké školy. Zbytek žáků $(n=45)$ 
uvedl, že je absolvované laboratorní cvičení bavilo srovnatelně se cvičeními ve škole. Žádného z žáků nebavilo toto cvičení méně než běžné cvičení ve škole.

Jak poukazují Franke \& Bogner (2011) a Scharfenberg \& Bogner (2013a,b), správně provedená laboratorní cvičení z molekulární biologie mohou pomoci pochopení obsahu i napravení miskoncepcí žáků. Tato skutečnost, spolu s vysoce pozitivním vnímáním pokročilých laboratorních cvičení z molekulární biologie, výrazně podporuje zařazování tohoto typu cvičení jako doplněk běžné středoškolské výuky biologie.

\section{ZÁvĚR}

$\mathrm{V}$ této studii bylo ukázáno, že $\mathrm{v}$ povinných předmětech biologie a chemie většinou nejsou pokryty některé zásadní tematické kategorie molekulární biologie a ŠVP jednotlivých škol se v zastoupení těchto témat značně liší. Navíc výuka probíhá převážně izolovaně, nejčastěji v posledním ročníku povinné výuky biologie. Pokud je v nabídce volitelných seminářů možnost semináře zaměřeného na molekulární biologii, je o něj mezi žáky velký zájem. V rámci možnosti rozšǐření výuky molekulární biologie byla středoškolským učitelům ze strany UK PřF nabídnuta možnost absolvovat se žáky laboratorní cvičení z molekulární biologie. Tato cvičení byla žáky hodnocena jako atraktivní, dobře provedená s pochopitelným postupem a doprovázená srozumitelným úvodním výkladem. Pokud proběhla na půdě vysoké školy, byla hodnocena pozitivněji než když proběhla na střední škole. To, zda cvičení vedl vysokoškolský lektor nebo středoškolský učitel, mělo vliv na hodnocení atraktivity (vyšší pod vedením lektora) a srozumitelnosti úvodního výkladu (vyšší pod vedením středoškolského učitele). Výsledky naší studie ukázaly, že provedená praktická cvičení z molekulární biologie byla žáky vnímána jako atraktivní a srozumitelná.

Na základě zjištěných skutečností se domníváme, že by bylo vhodné zahájit odbornou diskuzi o současné podobě vzdělávacího obsahu vyučovacího předmětu biologie na gymnáziích na úrovni státních kurikulárních dokumentů (Rámcového vzdělávacího programu pro gymnázia). Jsme přesvědčeni, že současná obsahová podoba biologického kurikula na gymnáziu (např́íklad vzhledem k postavení molekulární biologie v kurikulu) plně neodráží současný stav poznání v biologii jako vědním oboru a neodpovídá $\mathrm{v}$ některých aspektech potřebám společenské praxe.

\section{PoDĚKOVÁNí}

Autoři př́spěvku by na tomto místě chtěli poděkovat RNDr. Olze Vránové, Ph.D., a RNDr. Davidu Kopeckému, Ph.D., za podnětné připomínky k systému kategorií pro hodnocení vzdělávacího obsahu molekulární biologie na úrovni ŠVP gymnázií a Stevenu Morrisovi, M.A., za revizi anglické verze abstraktu. Velký dík patří také RNDr. Pavlu Vařejkovi za poskytnutí detailních informací a materiálů týkajících se volitelného semináře „Molekulární biologie“ na Gymnáziu Brno, třída Kapitána Jaroše 14.

Př́spěvek byl zpracován v rámci řešení grantových projektů OPVK CZ.1.07/2.3.00/ 20.0166 „Centrum teorie vzdělávání přírodovědných oborů“, IGA_PdF_2014019 a GAUK 1168214.

Oba autoři se na zpracování příspěvku podíleli ve stejné míře. 


\section{LITERATURA}

Adresář škol a školských zař́zení - revize 121203 (2014). Praha: Ministerstvo mládeže, školství a tělovýchovy a Ústav pro informace ve vzdělávání. Dostupné z http://stistko.uiv.cz/registr/vybskolrn.asp

Balgopal, M. \& Bondy, C. (2011). Antigenic shift and drift. Science Teacher, 78(2), $42-46$.

Ben-Nun, B. S., Stolarsky, M. \& Yarden, A. (2009). Learning molecular genetics in teacher-led outreach laboratories. Journal of Biological Education, 44(1), 19-25.

Bowling, B., Zimmer, E. \& Pyatt, R. E. (2014). Bringing next-generation sequencing into the classroom through a comparison of molecular biology techniques. The American Biology Teacher, 76(6), 396-401.

Byrd, J. J. (2000). Teaching outside the (cereal) box: a molecular genetics activity. The American Biology Teacher, 62(7), 508-511.

Cohen, L., Manion, L. \& Morrison, K. (2011). Research methods in education. New York: Routledge.

Costenson, K. \& Lawson, A. E. (1986). Why isn't inquiry used in more classrooms? The American Biology Teacher, 48(3), 150-158.

Donovan, J. \& Venville, G. (2005). A concrete model for teaching about genes and DNA to young students. Teaching Science, 51(4), 29-31.

Drits-Esser, D., Malone, M., Barber, N. C. \& Stark, L. A. (2014). Beyond the central dogma. The American Biology Teacher, 76(6), 365-369.

Falteisek, L., Černý, J. \& Janštová, V. (2013). Simplified technique to evaluate human CCR5 genetic polymorphism. The American Biology Teacher, 75(9), 704-707.

Franke, G. \& Bogner, F. X. (2011). Conceptual change in students' molecular biology education: tilting at wind mills? Journal of Educational Research, 104(1), 7-18.

Gavora, P. (2010). Úvod do pedagogického výzkumu. Brno: Paido.

Gallagher, S. R., Coon, W., Donley, K., Scott, A. \& Goldberg, D. S. (2011). A First attempt to bring computational biology into advanced high school biology classrooms. PLoS Computational Biology, 7(10), e1002244.

Gelbart, H., Brill, G. \& Yarden, A. (2009). The impact of a web-based research simulation in bioinformatics on students' understanding of genetics. Research in Science Education, 39(5), 725-751.

Gelbart, H. \& Yarden, A. (2006). Learning genetics through an authentic research simulation in bioinformatics. Journal of Biological Education, 40(3), 107-112.

German, P. J. (1996). Analysis of nine school biology laboratory manuals: promoting scientific inquiry. Journal of Research in Science Teaching, 33(5), 475-499.

Gormally, C., Brickman, P., Hallar, B. \& Armstrong, N. (2009). Effects of inquiry-based learning on students' science literacy skills and confidence. International Journal for the Scholarship of Teaching and Learning, 3(2), 1-22.

Imperial, S. \& Boronat, A. (2005). Determination of the Rh factor: a practical illustrating the use of the polymerase chain reaction. Biochemistry and Molecular Biology Education, 33(1), 50-53. 
Janík, T., Knecht, P., Najvar, P., Pavlas, T., Slavík, J. \& Solnička, D. (2010a). Kurikulární reforma na gymnáziích v rozhovorech s koordinátory pilotních a partnerských škol. Praha: Výzkumný ústav pedagogický v Praze.

Janík, T., Janko, T., Knecht, P., Kubiatko, M., Najvar, P., Pavlas, T., Slavík, J., Solnička, D. \& Vlčková, K. (2010b). Kurikulární reforma na gymnáziích - výsledky dotazníkového šetření. Praha: Výzkumný ústav pedagogický v Praze.

Janík, T. \& Slavík, J. (2007). Vztah obor-vyučovací předmět jako metodologický problém. Orbis scholae, 2(1), 54-66.

Janštová, V., Pavlasová, L. \& Černý, J. (2014). Inquiry based practical course focused on proteins. In Rusek, M. \& Stárková, D. (Eds.). Projektové vyučováni v př́rodovědných předmětech. Praha: Pedagogická fakulta Univerzity Karlovy v Praze.

Kidman, G. (2008). Biotechnology education: topics of interest to students and teachers. In Hamman, M., Reiss, M., Boulter, C. \& Tunnicliffe, S. D. (Eds.). Biology in context: learning and teaching for the twenty-first century. London: Institute of Education, University of London.

Kočárek, E. (2004). Genetika. Praha: Scientia.

Lewis, J. \& Wood-Robinson, C. (2000). Genes, chromosomes, cell division and inheritance - do students see any relationship? International Journal of Science Education, 22(2), 177-195.

Malacinski, G. M. \& Zell, P. W. (1996). Manipulating the "invisible": learning molecular biology using inexpensive models. The American Biology Teacher, 58(7), 428-432.

Miller, K. R. \& Levine, J. S. (2010). Biology (student edition). Boston: Pearson Education, Inc.

Ministerstvo školství, mládeže a tělovýchovy Ceské republiky (1999). Učební dokumenty pro gymnázia. Praha: Nakladatelství Fortuna.

National Committee on Science Education Standards and Assessment (1996). National Science Education Standards. Washington, D. C.: National Research Council, National Academy Press.

Nurse, P. (2003). The great ideas of biology. Clinical Medicine, 3(6), 560-568.

Offner, S. \& Pohlman, R. F. (2010). Visualizing proteins \& their Evolution. The American Biology Teacher, 72(6), 373-376.

Ondřej, V. \& Dvořák, P. (2012). Bioinformatics: A history of evolution "in silico". Journal of Biological Education, 46(4), 252-259.

Papáček, M. (2010). Badatelsky orientované př́rodovědné vyučování - cesta pro vzdělávání generací Y, Z a alfa? Scientia in educatione, 1(1), 33-49.

Rámcový vzdělávací program pro gymnázia (2007). Praha: Výzkumný ústav pedagogický v Praze. Dostupné z

http://www.vuppraha.cz/wp-content/uploads/2009/12/RVPG-2007-07_final.pdf

Rejstř́k škol a školských zařizení - verze 2.39 (2014). Praha: Ministerstvo mládeže, školství a tělovýchovy. Dostupné z http://rejskol.msmt.cz/

Scharfenberg, F. J. \& Bogner, F. X. (2013a). Instructional efficiency of tutoring in an outreach gene technology laboratory. Research in Science Education, 43(3), 1267-1288.

Scharfenberg, F. J. \& Bogner, F. X. (2013b). Teaching gene technology in an outreach lab: students' assigned cognitive load clusters and the clusters' relationships to learner 
characteristics, laboratory variables, and cognitive achievement. Research in Science Education, 43(1), 141-161.

Srinivasan (1998). Exploring the limitations of the 'DNA as a videotape' analogy. Journal of Biological Education, 33(1), 42-44.

Šmarda, J. (2003). Genetika pro gymnázia. Praha: Nakladatelství Fortuna.

Tsui, C.-Y. \& Treagust, D. (2003). Learning genetics with computer dragons. Journal of Biological Education, 37(2), 96-98.

Tsui, C.-Y. \& Treagust, D. (2007). Understanding genetics: Analysis of secondary students' conceptual status. Journal of Research in Science Teaching, 44(2), 205-235.

van den Berg, E. (2013). Didaktická znalost obsahu v laboratorní výuce: od práce s př́stroji k práci s myšlenkami. Scientia in educatione, 4(2), 74-92.

Vařejka, P. (2012). Maturitní témata z molekulární biologie. Brno: Gymnázium, tř́ída Kapitána Jaroše 14.

Venville, G. \& Donovan, J. (2006). Analogies for life: a subjective view of analogies and metaphors used to teach about genes and DNA. Teaching Science: The Journal of the Australian Science Teachers Association, 52(1), 18-22.

Vidal, M. (2009). A unifying view of 21st century systems biology. FEBS Letters, $583(24), 3891-3894$.

Wefer, S. H. \& Anderson, O. R. (2008). Identification of students' content mastery and cognitive and affective percepts of a bioinformatics miniunit: a case study with recommendations for teacher education. Journal of Science Teacher Education, 19(4), $355-373$.

Wefer, S. H. \& Sheppard, K. (2008). Bioinformatics in high school biology curricula: a study of state science standards. CBE-Life Sciences Education, 7(1), 155-162.

Wood, L. \& Gebhardt, P. (2013). Bioinformatics goes to school - new avenues for teaching contemporary biology. PLoS Computational Biology, 9(6), e1003089.

Woody, S. \& Himelblau, E. (2013). Understanding \& teaching genetics using analogies. The American Biology Teacher, 75(9), 664-669.

Platnost všech internetových odkazů uvedených v seznamu literatury byla ověřena autory př́spěvku ke dni 20. lednu 2015.

VANDA JANŠTOVÁ, vanda.janstova@natur.cuni.cz

Univerzita Karlova v Praze, Př́rodovědecká fakulta

Katedra učitelství a didaktiky biologie

Viničná 7, 12843 Praha 2, Česká republika

Univerzita Karlova v Praze, Pedagogická fakulta

Katedra biologie a environmentálních studií

M. D. Rettigové 4, 11639 Praha 1, Česká republika

MARTIN JÁČ, martin.jac@upol.cz

Univerzita Palackého v Olomouci, Pedagogická fakulta

Katedra biologie

Purkrabská 2, 77900 Olomouc, Česká republika 